\title{
Old and recent processes in a warm and humid desert hypogene cave: 'A'rak Na'asane, Israel
}

\author{
Amos Frumkin ${ }^{1 *}$, Shlomi Aharon ${ }^{2}$, Uri Davidovich ${ }^{3}$, Boaz Langford ${ }^{1}$, Yoav Negev ${ }^{1}$, \\ Micka Ullman ${ }^{1,3}$, Anton Vaks ${ }^{4}$, Shemesh Ya'aran ${ }^{1}$, and Boaz Zissu ${ }^{5}$ \\ ${ }^{1}$ Cave Research Center, Institute of Earth Sciences, The Hebrew University of Jerusalem, 9190401, Israel \\ ${ }^{2}$ The Arachnid National Natural History Collection, The Hebrew University of Jerusalem, Edmond J. Safra Campus, Givat Ram, \\ Jerusalem, 9190401, Israel \\ ${ }^{3}$ Institute of Archaeology, The Hebrew University of Jerusalem, 9190501, Israel \\ ${ }^{4}$ Geological Survey of Israel, 30 Malkhey Israel Street, 9550161 Jerusalem, Israel \\ ${ }^{5}$ Institute of Archaeology, The Martin (Szusz) Department of Land of Israel Studies and Archaeology, Bar-Ilan University, Ramat Gan, Israel
}

\begin{abstract}
Recent environmental processes are studied in 'A'rak Na'asane Cave at the northern Judean Desert, Israel. The outer zone of the cave is heavily influenced by the outside environment through a large entrance, facilitating entry of air flow, fauna and humans, with minor caveforming modifications. Conversely, the inner cave sustains humid and warm conditions, favoring modifications by condensation corrosion of convective air flow, associated with deposition of popcorn speleothems at the lower parts of dissolution pockets. The warm humid air of the inner cave may be associated with an underlying thermal water table. Active condensation corrosion is decreasing, possibly because of gradual change in the cave microclimate, associated with falling water table and ventilation. Increasing connection with the surface is indicated by high collapse domes, rare flood invasion, and a large Trident Leaf-nosed bat community which spends the winter within the innermost parts of the cave. Bat guano supports bedrock corrosion and a rich invertebrate fauna, but humans preferred the outer parts of the cave, particularly for refuge during the second Jewish revolt against the Romans. Rare occasions of ancient human entry into the inner cave support this scenario by the small number of artifacts compared with the outer cave. Enigmatic small cairns in the largest inner hall were probably erected during the Intermediate Bronze Age.
\end{abstract}

Keywords: $\quad$ confined cave, cave microclimate, condensation corrosion, bat guano, popcorn speleothem Received 15 January 2018; Revised 30 May 2018; Accepted 6 June 2018

Citation: $\quad$ Frumkin A., Aharon S., Davidovich U., Langford B., Negev Y., Ullman M., Vaks A., Ya'aran S. and Zissu B., 2018. Old and recent processes in a warm and humid desert hypogene cave: 'A'rak Na'asane, Israel. International Journal of Speleology, 47 (3), 307-321. Tampa, FL (USA) ISSN 0392-6672 https://doi.org/10.5038/1827-806X.47.3.2178

\section{INTRODUCTION}

Hypogene caves differ from epigene caves both in speleogenesis and later processes. Those located under arid conditions that are not invaded by epigene streams or dripwater, can retain unique environment due to lack of flowing water, contrasting with upward flow of heat and vapor. Following erosional breaching, such caves may develop a special set of features which reflect both their hypogene heritage and the increasing connection with the surface.

During recent years, speleogenesis of hypogene caves underwent increasing research (Chavez \& Reehling, 2016; Klimchouk et al., 2017, and references therein). However, post-speleogenesis processes peculiar to these caves have attracted less studies. Here we discuss various aspects of 'A'rak Na'asane (Fig. 1), a cave which may serve as an example of possible post-formational processes. An emphasis was made to cover various aspects of the cave, including geology, geomorphology, microclimate, biology and archaeology.

The cave is located at Nahal Dlayah (Arabic: Wadi edDaliyeh), eastern Samaria, Israel (Long. 35.407476 Lat. $31.994938^{\circ}$ ). It is the northernmost large cave in the Judean Desert region of well-developed hypogene caves (Frumkin et al., 2017a,b).

\section{GEOLOGY}

The cave is developed mainly within hard lower Turonian (upper Cretaceous) limestone of Shivta 


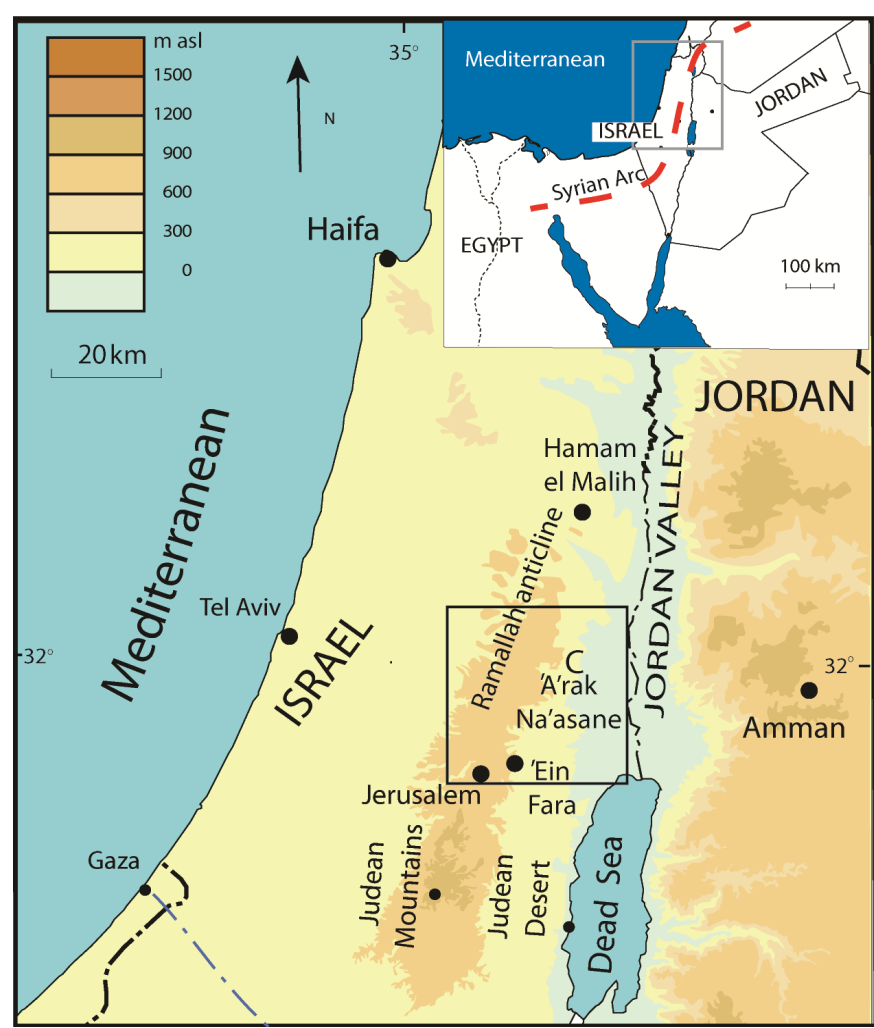

Fig. 1.Location topographic map. Rectangle indicates Fig. 4.

Formation. On the surface it is a cliff-forming unit, cropping out along the walls of Nahal Dlayah and forming its sub-vertical cliffs, up to $20 \mathrm{~m}$ high (Fig. 2). The lower member of Shivta Formation consists of dark-grey limey dolomite. The upper member, in which most of the cave is developed, consists of thickbedded, mud-supported biomicrite or pelbiomicrite, and mud-supported to grain-supported biosparite or pelbiosparite. This rock type includes well-rounded bioclasts (Begin 1974). The bedrock intersected by the cave is commonly white, but on the surface outside the cave it is covered by grey patina. The Shivta Formation was deposited in an open sea with high mechanical energy.

The cave intersects several quartzolite lenses and segmented quartzolite layers, up to $\sim 0.5 \mathrm{~m}$ thick (Fig. 3a), which are typical to the top of Shivta Formation. The term quartzolite refers to hard and hardly soluble, coarse to finely crystalline silicified rock. It preserves marine Turonian fossils perfectly, such as burial accumulations of Nerinea sp. (e.g., at the top of chamber F, Fig. 3b). The quartzolite commonly protrudes from the surrounding carbonate rocks due to the quartz durability.

Occasionally, high cupolas and domes reach the stratigraphically higher Turonian-Coniacian Nezer Formation, the uppermost formation of the Judea Group. Its base is a $\sim 3 \mathrm{~m}$ thick marl bed, overlain by thickly-bedded, finely-crystalline dolomite with some limestone.

The cave is within the Auja Monocline, the eastern flexure of major anticline of this region (Fig. 2, 4, and 5). This anticline is a part of the folded structures of the Syrian Arc (Fig. 1 inset) which started forming during the Turonian (Shahar 1994). At Nahal Dlayah, the Auja monocline strikes N-S. Following the layers of Shivta Formation, the cave passages are inclined along the dip of the monocline.

\section{SPELEOLOGICAL BACKGROUND}

'A'rak $\mathrm{Na}$ 'asane is one of many caves in the Judean Desert which developed under hypogene conditions, beneath the confining Mount Scopus Group aquitard. The processes that could interplay to form 'A'rak $\mathrm{Na}$ 'asane and associated caves were discussed earlier (Frumkin, 2017a,b), and will be presented shortly here.

The main speleogenetic phase of these caves occurred during the Oligocene-early Miocene, after the region emerged above the Eocene sea. During the initial speleogenetic period the regional relief was much flatter than today, and Judea Group was saturated with groundwater. As in other regions of the Judean Desert, a deep fault underlying the Auja monocline (Fig. 2, 3) could facilitate upward fluid migration across heterogeneous strata (Shahar, 1994). Fracturing across the convex-upward part of the monocline could provide focused upflow of deep fluids towards the confining regional aquitard of Mount Scopus Group. The cave developed at the optimal vertical location, at the uppermost massive, pure limestone of Shivta Formation. Within the preferential flow zone below the confinement, the hypogene water could mix with lateral epigene water flowing from the truncated anticline west of the cave. The aquitard cover was partly breached by the regional truncation surface since the Oligocene, enhancing vertical permeability.

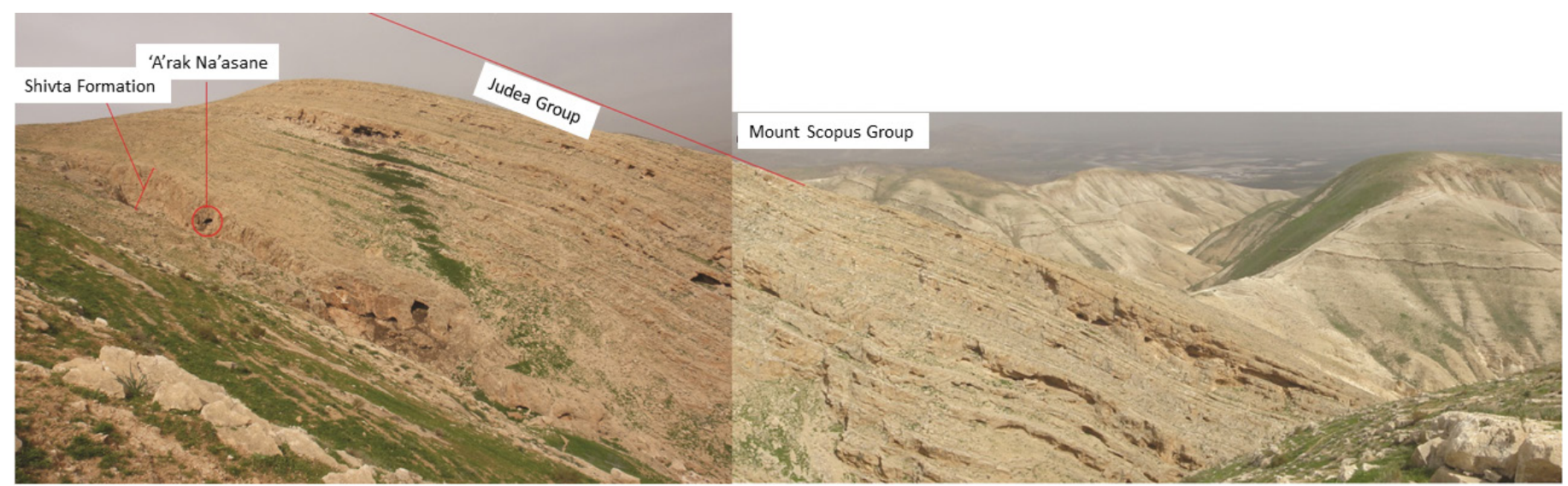

Fig. 2. 'A'rak Na'asane (Red circle, left) entrance in Judea Group limestone at the Auja monocline. The confining Mount Scopus aquitard was eroded on the left, remaining intact on the right. View to north. 
'A'rak Na'asane entrance altitude today is $134 \mathrm{~m}$ asl, but during speleogenesis it was probably closer to sea level. Since then, the cave has been dewatered due to the increasing relief.

During the Miocene the groundwater flow was partly disrupted by the initial formation of the Dead Sea transform between 18 and 16 Ma (Joffe \& Garfunkel, 1987), or closer to $14 \mathrm{Ma}$ (Bar et al., 2016). The regional groundwater flow shifted towards the Dead Sea morphotectonic depression, coupled with arching and uplift of the mountain ridge west of the rift valley. Upwelling groundwater was mostly diverted to the new base level of the Dead Sea basin. The Dead Sea Transform and associated rifting juxtaposed the site of 'A'rak Na'asane along the developing Dead Sea Jordan Depression. This newly formed depression attracted further deep flow as common in rifting zones (Klimchouk, 2017).

The coupled effect of the deep Syrian Arc fault and the younger Dead Sea depression faults played a more important role in 'A'rak $\mathrm{Na}^{\prime}$ asane than in other Judean Desert caves, which formed either along less-developed monoclines or farther away from the Dead Sea depression (Frumkin et al., 2017b). Thus, 'A'rak Na'asane probably supported focused crossformational upward flow and hypogene karstification for long-enough time to create the largest maze cave in Israel (by volume).
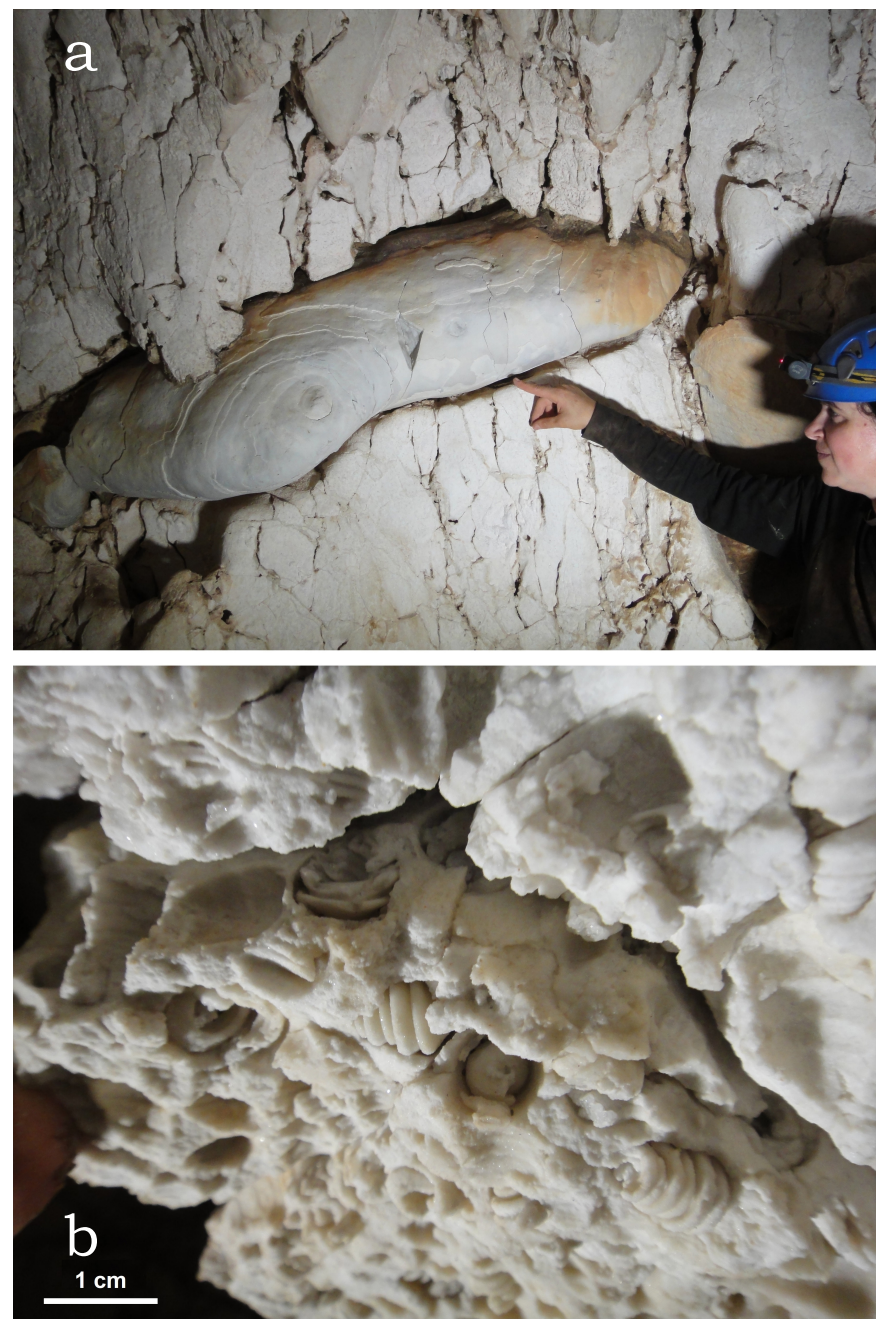

Fig. 3. a) Quartzolite lense within limestone etched by dissolution in the cave; b) Nerinea sp. fossils replaced by quartz in a Quartzolite layer.

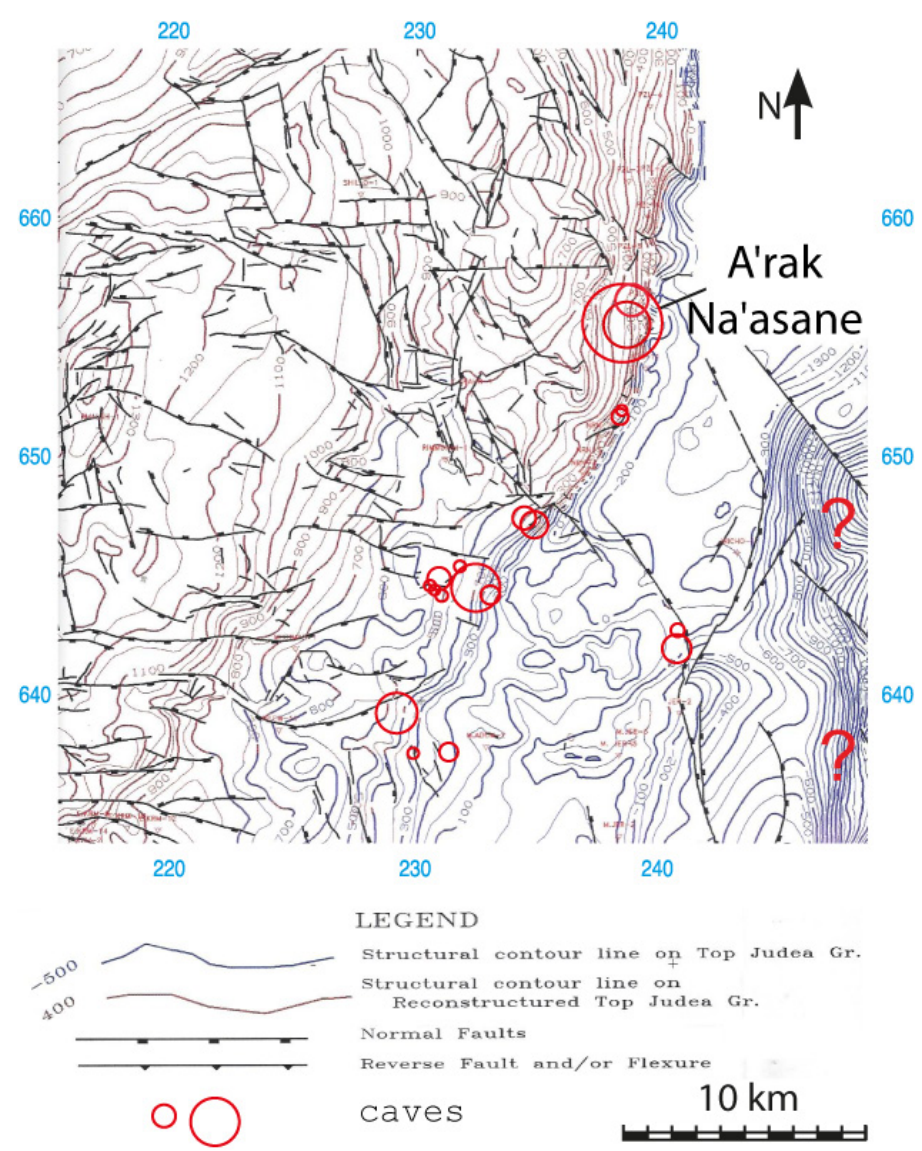

Fig. 4. 'A'rak Na'asane on a structural map. Contour interval $50 \mathrm{~m}$. Red circles indicate hypogene caves, with radius proportional to cave length. Caves are concentrated mainly along the Auja monocline. New Israel Grid, modified after Fleischer \& Gafsou (2000). See Fig. 1 for location. Israel Transverse Mercator Grid coordinates.

Following the increasing relief between the subsiding Dead Sea - Jordan Valley and its uplifting shoulders, the water table dropped below the cave, and fluvial erosion dissected the surface. The small canyon of Nahal Dlayah, which flows to the Jordan Valley, breached the cave, forming a single entrance at the northern wall of the canyon (Fig. 2). 'A'rak Na'asane is the largest cave in this canyon, which boasts several hypogene caves (Frumkin 2015) (Fig. 6).

The purpose of this paper is to discuss features and processes of the later stages of the cave evolution, following its dewatering and breaching by Nahal Dlayah. These include geogenic, biogenic and anthropogenic features which seem to differ from epigene caves, and thus contribute to understanding the late history of hypogene caves.

\section{METHODS}

A new survey of the cave was performed according to common speleological survey standards, Grade 5C (Fig. 7,8 ). Most of the surveyed length and volume was newly discovered in 2017, during the present study, by careful monitoring of air currents and enlargement of tight passages.

Temperature, relative humidity and major gases were measured at selected sites along the cave, on two visits during December 2017, using temperature, humidity and gas meters. The visit on December 31 was accompanied by better calibration of the equipment, hence its measurements are used throughout the 


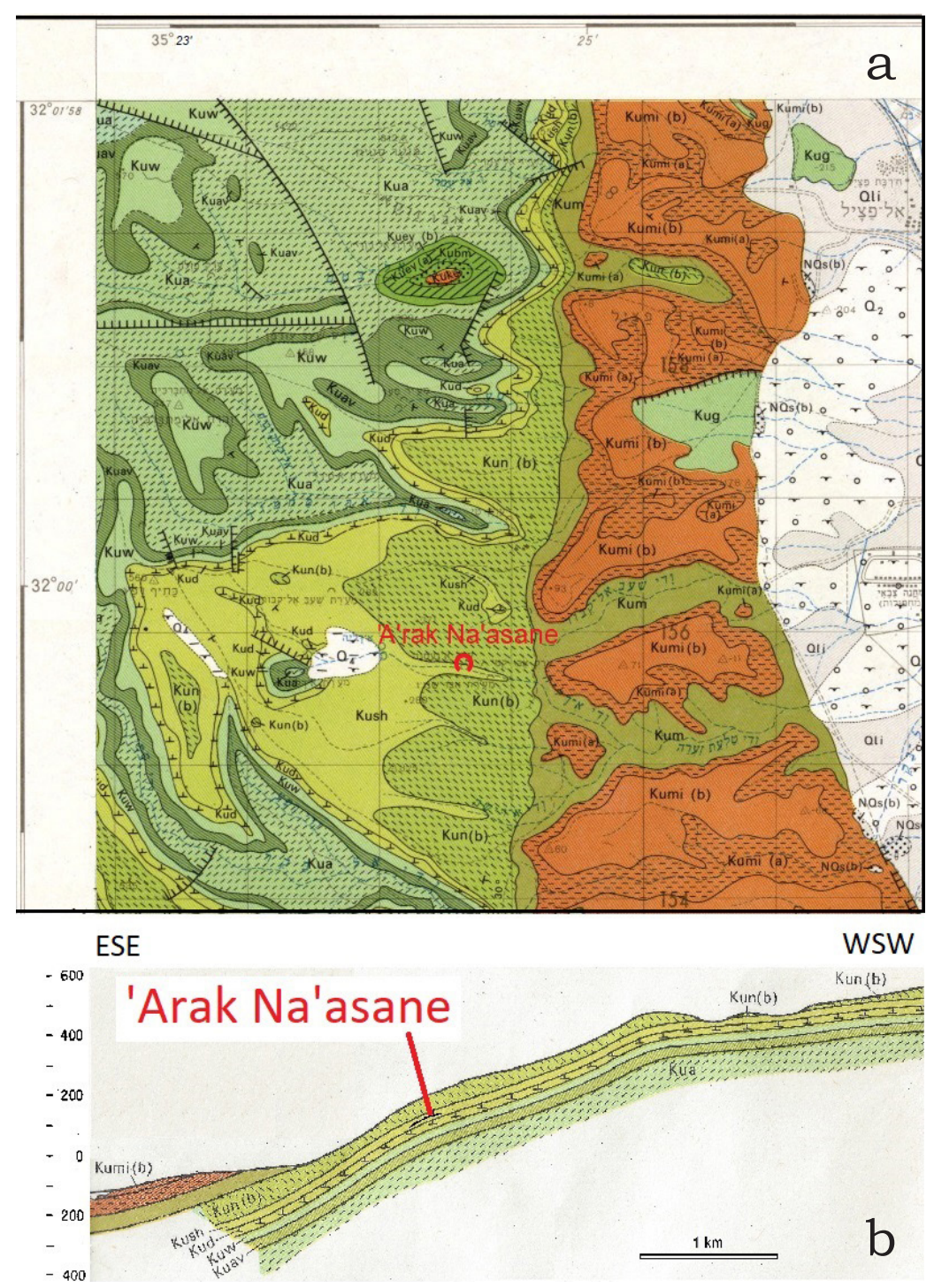

Fig. 5. Geology of 'A'rak Na'asane vicinity, modified after Begin (1974). a) Geological map. Green outcrops of the left half are Judea Group limestones and dolomites.

Olive to brown on central right are remains of the confining aquitard of Mount Scopus Group. White on extreme right is Quaternary fill of the Jordan Rift Valley; b) Geological section across the Auja monocline with projected location of A'rak Na'asane. Elevation in $\mathrm{m}$ above and below sea level. Israel Grid and global coordinates.

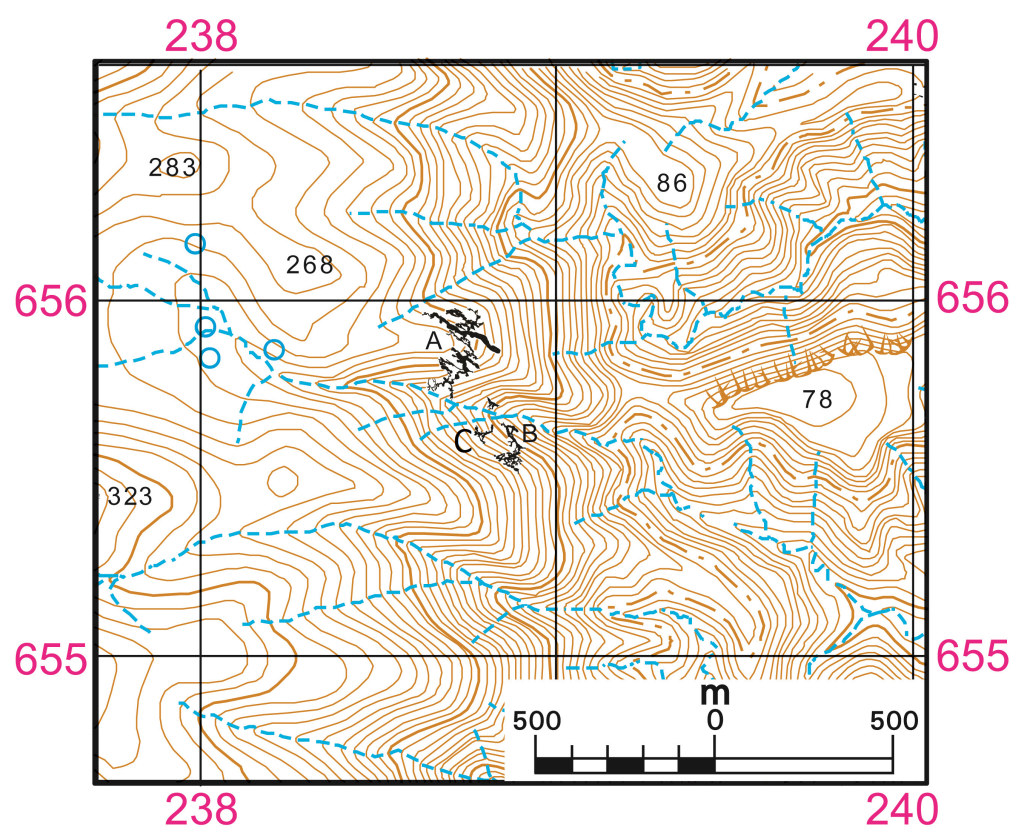

Fig. 6. Topography of Nahal Dlayah (10 m contour interval) with projections of the major caves. A) 'A'rak Na'asane; B) Yogev Cave; C) Mugharet Abu-Shinjeh. Israel Transverse Mercator Grid coordinates. paper, but December 15 measurements are also used. Each measurement was taken once the device value was stable, using UNI-T UT333-Mini Temperature \& Humidity Meter, and SNDWAY SW-825 PM 2.5, Temperature and Humidity meter.

In addition, cave air was sampled December 31 2017, and analyzed in the laboratory. Air samples were collected into vacuumed $3 \mathrm{ml}$ sampling flasks. Filling of the flask with the sample air was performed by opening the flask tap for 2-4 seconds and then closing it in the sampling location. One sample of atmospheric air was taken outside before entering the cave (Fig. 9). The other ten samples were taken in pairs in the following locations of Fig. 9: 1, 2, 12 (one sample leaked and was lost), 7, and 8. The cave air samples were analyzed for $\mathrm{O}_{2}$ and $\mathrm{CO}_{2}$ contents by Hampadah System in The Hebrew University of Jerusalem, by the method described in Hilman \& Angert (2016).

Morphologic and sedimentary features were recorded across the cave by inspection and photographs. Archaeological survey was performed across the cave, with emphasis on its newly discovered parts. The finds were cleaned and identified in the laboratory by correlation with similar artefacts. Fauna was recorded across the ecological niches of the cave, and arthropod specimens were sampled for identification in the laboratory.

\section{ARCHAEOLOGY AND HISTORY OF EXPLORATION}

Bedouins from the Ta'amireh tribe looted the nearby Mugharet Abu-Shinjeh Cave (Fig. 6) in the early 1960s, and discovered 18 legal papyri and their clay sealings (bullae) as well as two gold seal rings from the end of the Achaemenid Period. The legal documents were written in Aramaic in the city of Samaria during the fourth century $\mathrm{BCE}$, and were brought to Mugharet Abu-Shinjeh by residents of the city who rebelled against Alexander the Great in 331 $\mathrm{BCE}$ and fled the Macedonian reprisals (WinnLeith, 1997; Gropp, 2001; Dušek, 2007).

As a result of these outstanding discoveries, an expedition to Wadi ed-Daliyeh caves was organized by the American School of Oriental Research (ASOR) in Jerusalem. The excavations were conducted by Paul and Nancy Lapp, during 1963-1964. 'A'rak Na'asane was briefly explored and only partly excavated by the Lapps, who labelled it "Cave 2", since their main interest was in Mugharet Abu-Shinjeh, "Cave 1". The ASOR expedition excavated in the outer wing (Fig. 7 Halls A-B-D) of 'A'rak Na'asane, and reported finding large artifact assemblages from two phases - Intermediate Bronze Age (IBA, 2350$2000 \mathrm{BCE})$, and Roman period ( $2^{\text {nd }}$ century $\mathrm{CE})$ - as well as more isolated finds from the Middle Bronze Age (MBA, 2000-1550 BCE), Iron 
Age (1140-586 BCE), and Mamluk period (1250-1517 CE). The finds were presented and discussed in the final report of the excavations (Lapp \& Lapp 1974).

The central parts (up to chamber M-N) of 'A'rak $\mathrm{Na}$ 'asane were first investigated and mapped by the Israel Cave Research Center (ICRC) in 1980, after renewed looting by the Bedouins. During the following years, the ICRC continued the exploration of caves along the cliffs and slopes of Nahal Dlayah (Frumkin \& Langford, 2015; Frumkin, 2015: 156-171; and lit. cit. there).

The outer segments of the cave, up to Chamber D, contained numerous IBA burials that were excavated by the ASOR expedition; these burials were accompanied by several burial goods each (mainly ceramics; Fig. 10a), and generally resemble burial assemblages found in other IBA cemeteries of the central highlands of the southern Levant (Dever in Lapp \& Lapp, 1974). Another rich assemblage found in Halls B-D of the cave was attributed to the Bar Kokhba revolt (132-136 CE). The finds included an assemblage typically found in the Judean Desert refuge caves: a bronze coin of the Bar Kokhba administration (Fig. 11), apparently from the last year of the war,

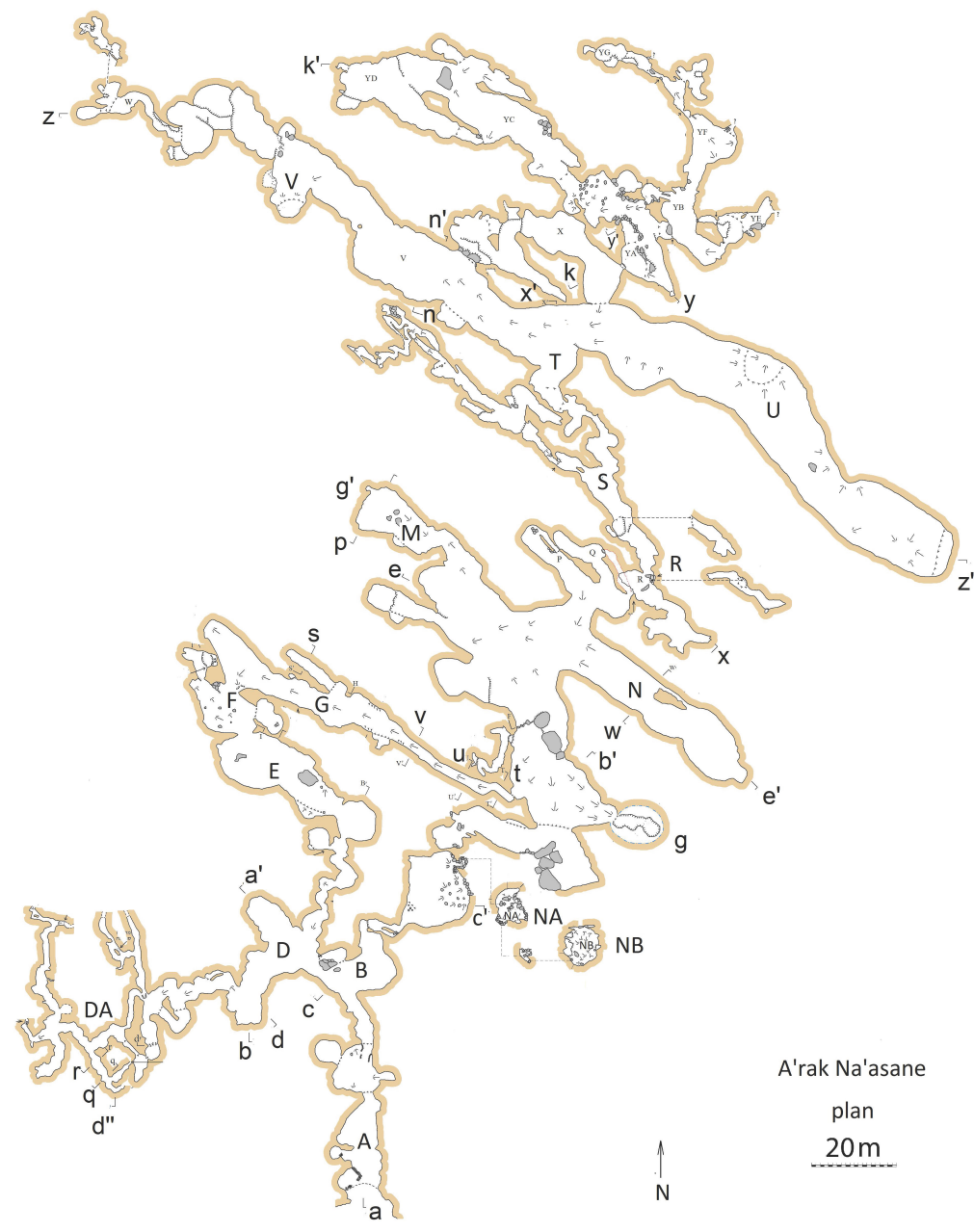

Fig. 7. Plan of 'A'rak Na'asane, surveyed by Boaz Langford, Shemesh Ya'aran, Micka Ullman, Vladimir Buslov, ICRC, 2011-2017, Grade 5C.

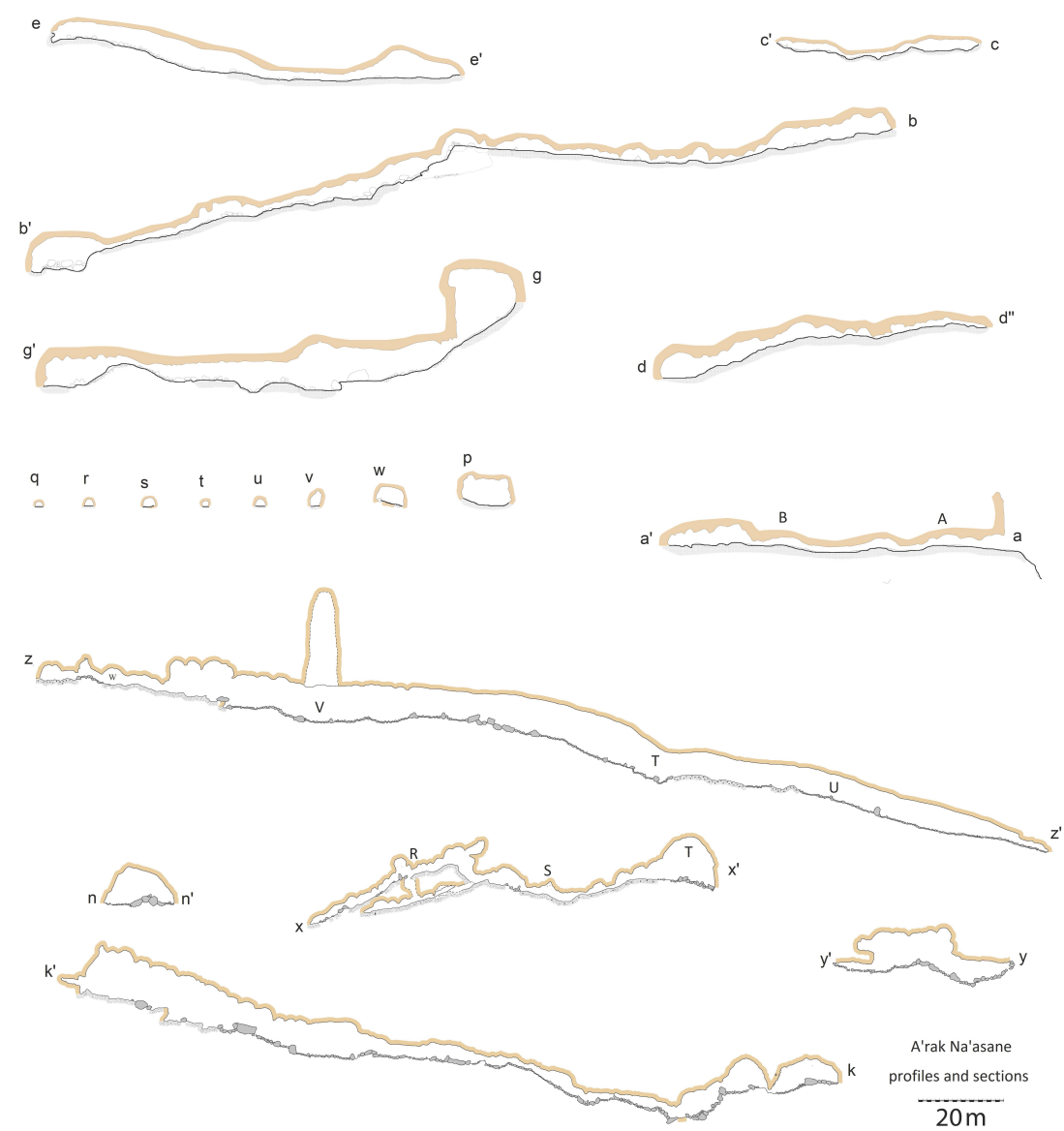

Fig. 8. Selected profiles and cross sections of 'A'rak Na'asane, surveyed by Boaz Langford, Shemesh Ya'aran, Micka Ullman, Vladimir Buslov, ICRC, 2011-2017, Grade 5C.

four elbow keys, pottery and glass vessels, two wooden combs, a decorated bronze handle, a wooden bowl and leather sandals, among other finds. In the 1980 ICRC explorations, a hoard of 16 silver denarii of Trajan and Hadrian was found, as well as a single tridrachm (Erlich \& Damati 1998), which also belonged to Jewish refugees who fled to the cave at the end of the Bar Kokhba revolt (Fig. 11) (Eshel, 1998).

In 2017, the authors, on behalf of the ICRC at the Hebrew University and the Department of Land of Israel Studies and Archaeology at Bar-Ilan University, conducted a renewed speleological and archaeological exploration of 'A'rak Na'asane, following antiquities looting. A full archaeological report of the 2017 explorations is under preparation.

A significant archaeological find of the renewed survey was two IBA lamps (Fig. 10b) found in a remote inner part of the cave (passage $R$ and underlying voids), further away from all previous finds from this period in the cave. These twolamps are the innermost material-cultural remains found to-date in the cave, and are indicative of an episodic penetration into the inner cave segments. Further inside, within the large hall zz', ca. 30 man-made small stone cairns (Fig. 12), each built of several small stones arranged one of top of the other in a haphazardly manner, were found. While direct dating of these cairns seems like an impossible task, the lack of any indication for recent human penetration into the inner segments of the cave (from passage $R$ 


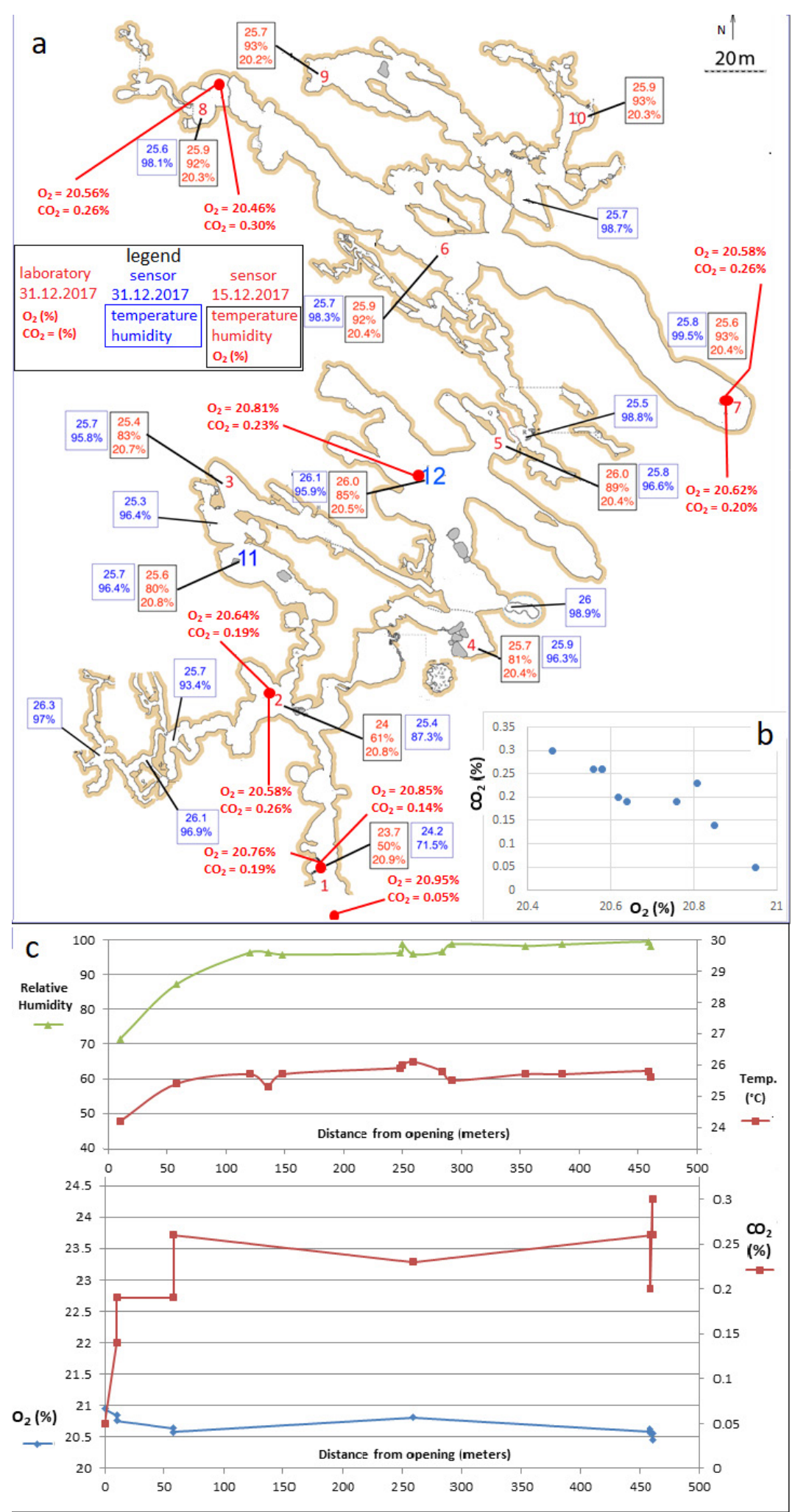

Fig. 9. Cave climate and gas measurements, December 2017. a) Measurements on cave map; b) $\mathrm{CO}_{2}$ as a function of $\mathrm{O}_{2}$ on 31 December 2017; c) Variations of temperature, relative humidity, and gases according to distance along the main cave passage on 31 December 2017.

onwards) prior to our 2017 survey, and the absence of material remains other than the aforementioned two IBA lamps, may imply that this section was briefly visited by humans sporadically and possibly only once, during the Intermediate Bronze Age. While speculative due to the meager archaeological data, it should be emphasized that the IBA was the only period during which people have entered the deepest segments of hypogene maze caves in the Judean Desert (Eshel, 1999; Frumkin, 2015), probably in relation to ritual activities, their nature yet unknown.

Roman period finds were also uncovered during the 2017 survey. This small assemblage was in chambers $\mathrm{NA}$ and $\mathrm{NB}$ (Fig. 7), two medium-sized high galleries not penetrated before, which branch off chamber $\mathrm{C}$ of the outer segment of the cave. On the northeastern side of this chamber there is a hidden and very difficult, partly collapsed passage which was first discovered in 2017. The passage leads to a series of upper voids with a total length of $33 \mathrm{~m}$. The first passage, between boulders and yellow clay debris, leads to cavity NA (dimensions $9 \times 5 \mathrm{~m}$; height $2.5 \mathrm{~m}$ ). The ground of cavity NA is covered with boulders; yellow clay overlying Shivta Formation is exposed along its western wall. In our survey, an intact cooking pot and a jug were found in this cavity. Both pottery vessels have parallels in archaeological assemblages of the first and early second centuries $\mathrm{CE}$.

From cavity NA, it is possible to climb a steep southward slope and pass through narrow crevices between boulders toward an upper cavity - NB (dimensions 7x10 m; maximal height $4 \mathrm{~m}$ ). This cavity is in fact the upper level of cavity NA and is full of rock debris, colored clay and many stratified layers of Nezer Formation bedrock.

An intact cooking pot and fragments of a Judean ("Darom") oil-lamp, both typical to the period between the two Jewish revolts against the Romans and the Bar Kokhba revolt, were found; some beads and few fragments of pottery from the IBA were found in this cavity as well.

In summary, the archaeological explorations conducted at 'A'rak Na'asane revealed evidence of substantial human activity during the Intermediate Bronze Age and during the Bar Kokhba Revolt. Few finds are associated with the MBA, Iron Age I, Byzantine, Early Islamic and Mamluk periods as well. The total absence of late Persian Period remains is intriguing, indicating that A'rak Na'asane, for reasons unknown, was not used by the Samaritan refugees which occupied the near-by, and much smaller, Abu-Shinjeh Cave.

It appears that Jewish refugees fled to the 'A'rak Na'asane cave from settlements in the eastern Samaria or from the Jordan Valley at the end of the Bar Kokhba Revolt. This was the northeastern-most refuge cave used during the Revolt. In contrast to other refuge caves, 'A'rak Na'asane has an easily reached entrance; the refugees apparently hoped that the depth of the cave and its remote location - away from roads and settlements - would ensure their safety. The absence of human bones in the cave, as opposed to other refuge caves (Frumkin, 2015 and references therein), raises 

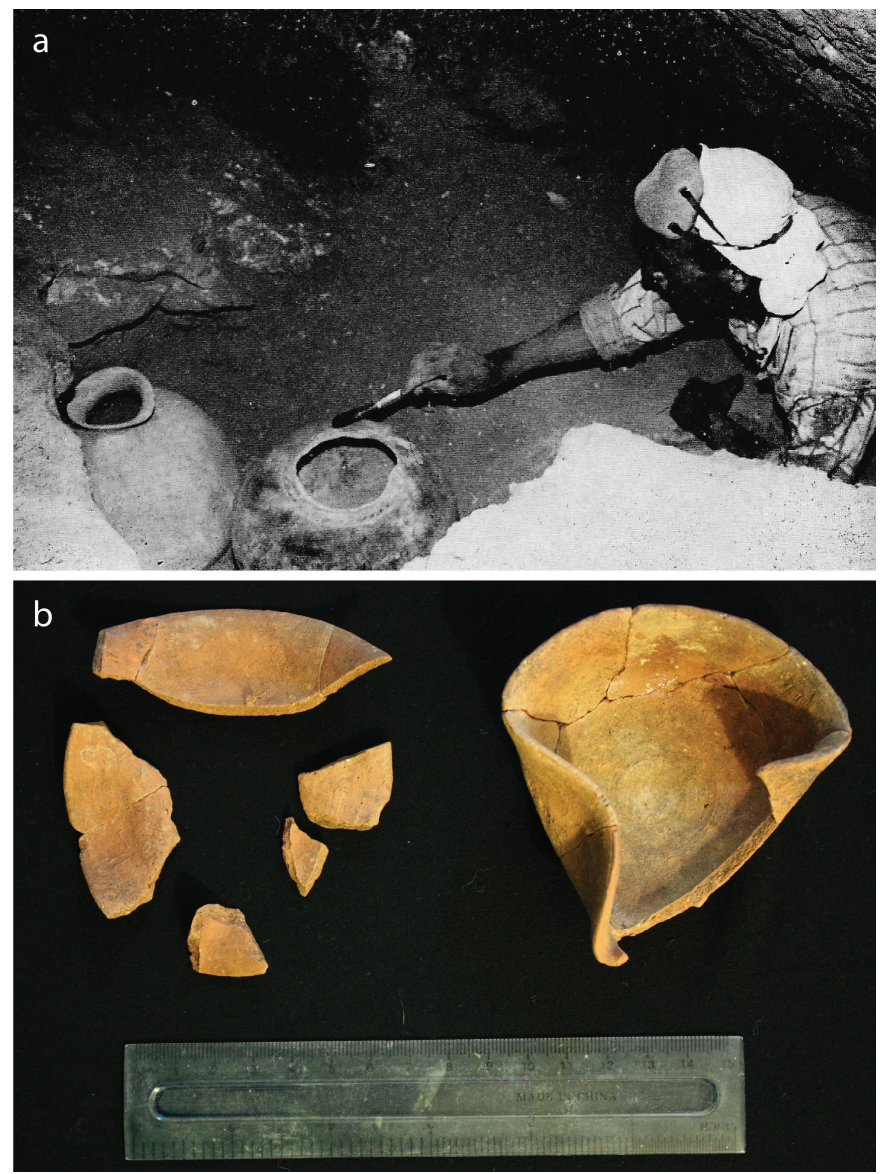

Fig. 10. Intermediate Bronze Age artifacts from A'rak Na'asane: a) pots as discovered (Lapp \& Lapp, 1974) near the cave entrance; b) oil-lamps from the inner part, locality $R$, discovered during the new ICRC survey (2017).

the possibility that the Jewish refugees survived the revolt.

\section{CLIMATE AND CAVE MICROCLIMATE}

Annual precipitation is $\sim 200 \mathrm{~mm}$, potential evaporation $\sim 1800 \mathrm{~mm}$, and mean annual temperature $\sim 21^{\circ} \mathrm{C}$. The cave is within the rain shadow, semi-arid part of Israel. Climate was wetter during the glacial periods (e.g., Vaks et al., 2003; Lisker et al., 2010) when the presently dry Jordan Valley east of the cave was inundated by Lake Lisan.

Measurements inside the cave were taken between the hours 6:30-19:30, showing a relatively narrow range of $24^{\circ} \mathrm{C}$ at the entrance (changing by hour and season), to $26^{\circ} \mathrm{C}$ inside the cave (Fig. 9). The relative humidity rises significantly the deeper one gets inside the cave, and range from $71.5 \%$ at the entrance up to $99.5 \%$ at the deepest sections. The floor cover appears to reflect the humidity levels as it varies from dry at the entrance to damp and muddy soil at the humid parts of the cave. There also seems to be a connection between the presence of bats at the different sections to the humidity levels in these sections: thousands of Trident Leaf-nosed bats colonize the deep, humid parts of the cave, but their presence might also increase the humidity.

Measured surface air temperature and relative humidity outside the cave entrance during the present study, December 2017, varied between $15.5-24^{\circ} \mathrm{C}$ and $55-70 \%$, respectively. Within the inner parts of the cave
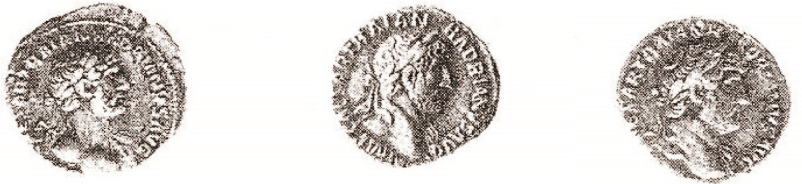

10

11

12
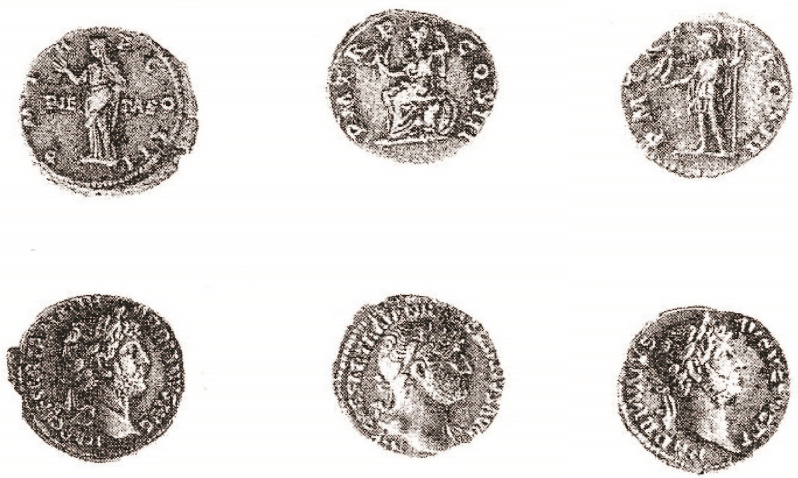

13

14

15
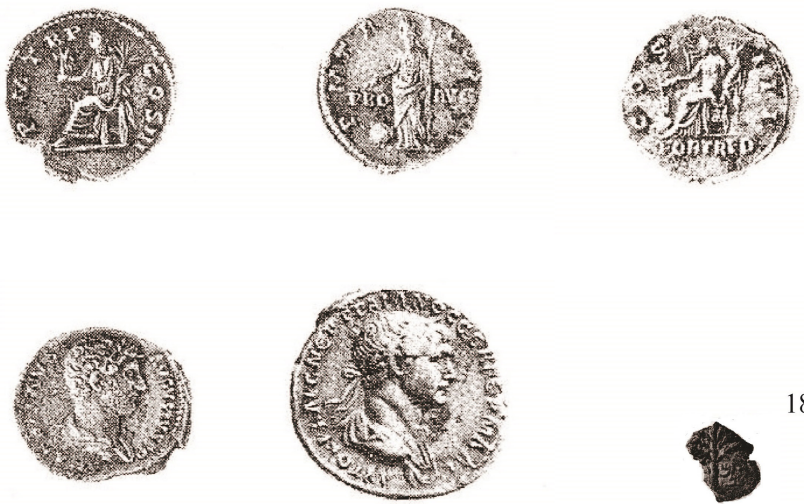

16

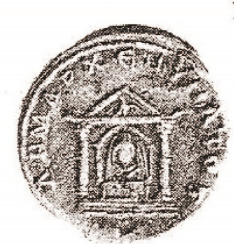

17

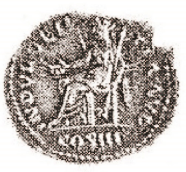

$1 \mathrm{~cm}$

Fig. 11. Finds from the Bar Kokhba revolt, sites B-D near the cave entrance. 10-16: Part of a hoard of silver denarii of Trajan and Hadrian; 17: tridrachm of Trajan; (Damati \& Erlich 1981; Erlich \& Damati, 1998); 18: Bronze coin of Bar Kokhba (Lapp, 1974). Scale - $1 \mathrm{~cm}$.

(from chamber $\mathrm{t}$ inwards) air temperature and relative humidity were consistently $25.5-26.1^{\circ} \mathrm{C}$ and 95.9$99.5 \%$ respectively, with local variations according to specific conditions such as air flow, condensation and biogenic activity. Between the entrance and the inner cave, the values rose gradually (Fig. 9c). High values were recorded also at the western maze ( $\mathrm{r}-\mathrm{d}$ "), with values of $25.7-26.3^{\circ} \mathrm{C}$ and $93.4-97 \%$, respectively. The relatively high values of the inner parts of the cave do not seem to change dramatically across the year, as indicated by our whole year visits, so the microclimate in the inner parts is warm, very humid and stable.

Laboratory analyses of oxygen and $\mathrm{CO}_{2}$ concentrations in the cave show that they gradually change from atmospheric values on the entrance $\left(\mathrm{O}_{2}=20.95 \%, \mathrm{CO}_{2}=0.05 \%\right)$ to the lowest concentration of $\mathrm{O}_{2}=20.56 \pm 0.05 \%$ and the highest concentration of $\mathrm{CO}_{2}=0.30 \pm 0.02 \%$ on station 8 (see Fig. 9 for details). Measurement with an oxygen sensor in additional locations show that oxygen concentration decreases to $20.2 \%$ in some places. An air current is observed along the cave voids, particularly in tight squeezes. 


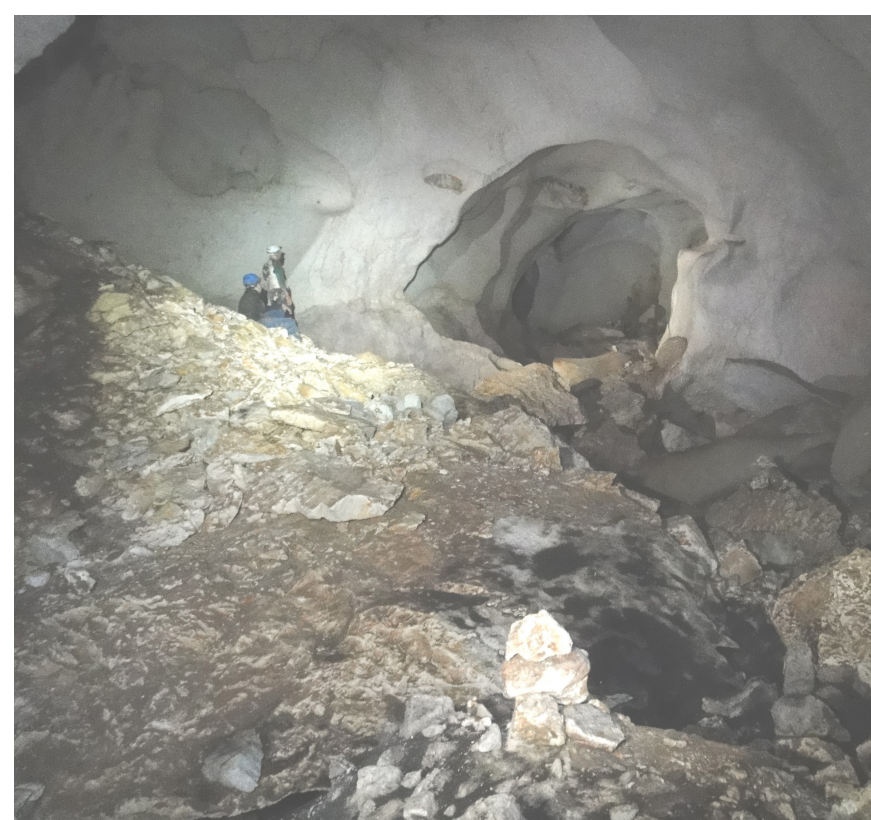

Fig. 12. A $20 \mathrm{~cm}$ high man-made small stone cairn, built of several small stones, within the large hall $(U)$.

Active gravity-driven water flow has hardly been observed. However, at some points the cave walls are damp. At site $\mathrm{g}$ the dampness seems to flow and accumulate on overhangs of the cave bedrock wall, forming occasional drips (Fig. 13a). At site y', 'popcorn' deposits are damp, and water drips hang at the bottom of the overhanging popcorn, occasionally gathering to form drips (Fig. 13b). The high relative humidity ( 99\%) of the air at these locations and the overall distribution of the dampness, without clear association to fractures, may suggest that the water is condensing from the cave air upon contact with cooler rock surfaces. This will be isotopically and chemically checked in the future. The bottom of the cave is damp within most of the cave inner parts, but dry at the outer segments, within tens of $\mathrm{m}$ from the entrance.

\section{CAVE MORPHOLOGY}

The total length of the cave according to the new survey is $2238 \mathrm{~m}$. Its maximal depth below the entrance is $52 \mathrm{~m}$. The total cave area is $8331 \mathrm{~m}^{2}$, and its volume is $35,161 \mathrm{~m}^{3}$. Of this, the major chamber $z$-z' occupies $2077 \mathrm{~m}^{2}$ and $13,643 \mathrm{~m}^{3}$ respectively. This is the largest passage in the Judean Desert by all its geometric features. In addition, 'A'rak $\mathrm{Na}$ 'asane is the largest cave in the Judean Desert by volume.

No rising half tubes or bubble trails were observed. However, so-called 'phreatic' or 'hypogene' morphology is common, including elliptical cross-section of passages, 'boneyard'-like tubes, smooth walls, cupolas, and solution pockets (Fig. 13c,d). These are encountered in most parts of the cave, although in some places this morphology is obscured, mainly due to mechanical breakdown of the ceiling.

In plan view, the cave resembles a rough maze composed of few large elongated chambers, directed to azimuth $\sim 120^{\circ}$, intersected by smaller passages which tend to undulate to various directions. Similar to other maze caves, 'A'rak Na'asane has a small areal coverage and large passage density. Most passages reach up to $3 \mathrm{~m}$ and rarely $10-15 \mathrm{~m}$ in width and height. Passages commonly occupy one tier and are not interconnected in complex networks. In certain places, such as site R, two tiers have developed. The passages appear to follow bedding planes along their intersection with fractures. Fractures and bedding planes are initially of sub-millimeter to sub-centimeter wide. Some are filled with secondary calcite deposit, but boxwork features are not well-developed.

Horizontal passages terminate abruptly or gradually. Rising shafts extend upwards from passages in some places. Those that extend upwards commonly terminate abruptly in smooth ceiling cupolas, commonly within Nezer Formation.
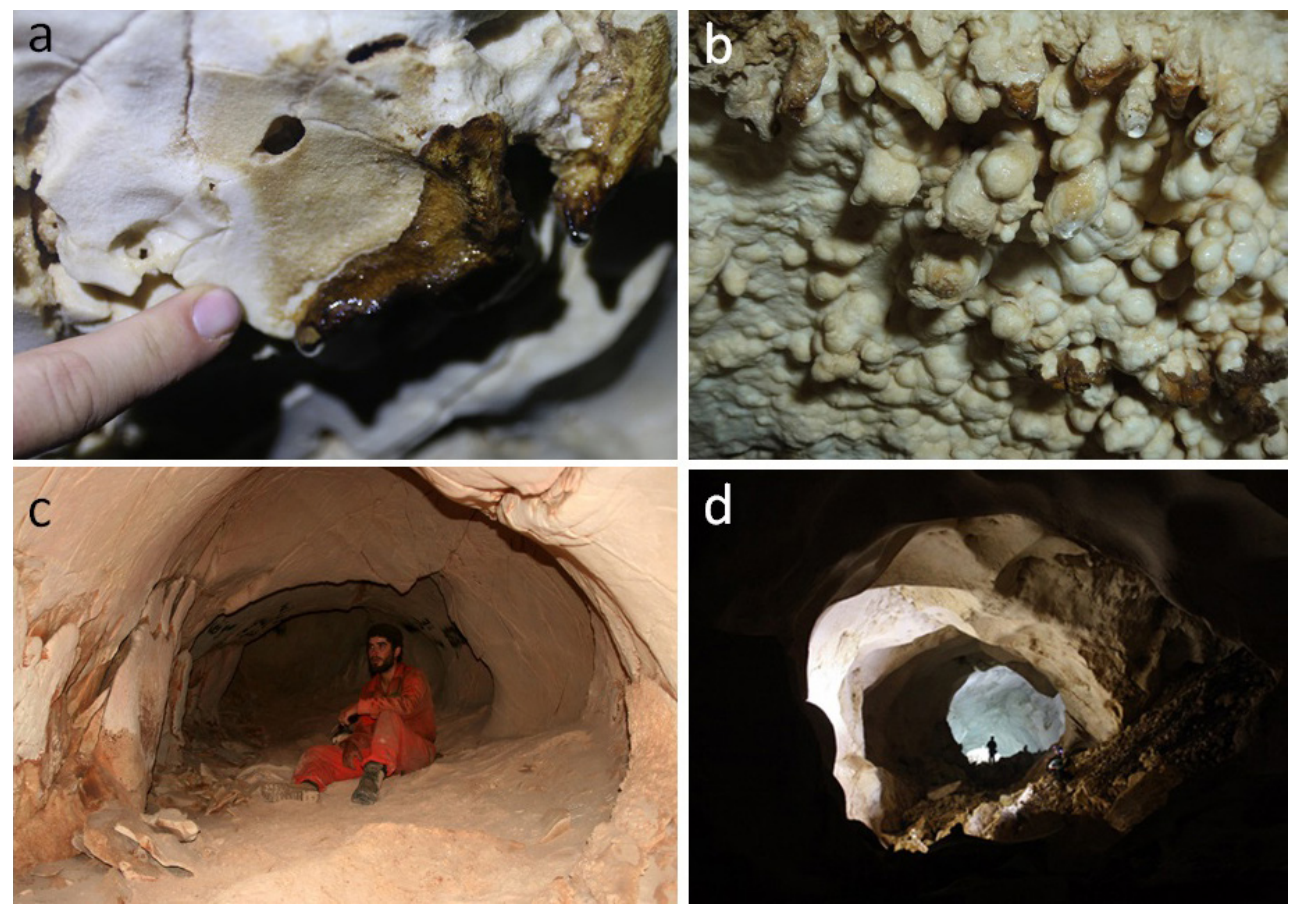

Fig. 13. a) Condensation water on bedrock and on bat urea stalactites; b) Condensation water on cave popcorn. Picture width $\sim 20 \mathrm{~cm}$; c) Elliptical passage at the outer part of the cave; d) Passage $z-z^{\prime}$ at the inner part of the cave, with cupolas. 
Scallops of fast-flowing water were not observed, but mudbanks (below) probably indicate flooding event(s) which invaded the cave in the past.

\section{CAVE DEPOSITS}

Detrital sediments indicative of fast-flowing water, such as pebbles are not observed within the cave. Gravity-controlled dripstones, such as stalactites or stalagmites are rare. Remnants of stalagmites were observed at the unroofed part outside the cave entrance. These may be related to specific subaerial conditions of the entrance, such as dripline effects of concentrated flow from the upper escarpment and soil outside the cave. The most common chemical deposits are cave 'popcorn' and 'corals', which will be discussed below. In some cases, the popcorn is associated with additional depositional features, such as bedded, flowstone-like calcite (Fig. 13a,b), bedded detritus (Fig. 14c), and rim-like deposits. In some places, few $\mathrm{mm}$ - or cm-thick deposits of calcite spar are observed, partly filling fractures (Fig. 14d).

Bat-guano deposits at the inner parts of the cave interact with underlying bedrock, dissolving it and forming corrosion rinds. The minerals formed during this process have yet to be determined (Fig. 15).

Dry mud banks composed of dark brown terra-rossa like clays are observed along R-T passage (Fig. 16a). Horizontal lines on the wall above the mudbanks indicate the paleo-water level which deposited the mud banks. The mud banks appear to represent a relatively recent event in the history of the cave, as it fills and covers condensation corrosion features, such as deeply incised cupolas and associated popcorn (below). The location of the mudbanks deep within the cave may indicate that the flood water and mud entered the cave from above, rather than from the present entrance. Another, less-likely possibility is that the mudbanks represent the latest groundwater stage in the cave, thus filling underwater voids with phreatic morphology.

Collapse features are rare along narrow passages, but more common in wider sections and chambers. The bottom of the largest passage $z-z$ ' is commonly covered with boulders of up to few $m$ in size. In few places, large collapse piles indicate partial collapse of the cave roof, such as at sites F, g, and NA-NB. During the recent study the collapsed pile of rocks at site NANB was climbed. Roman period vessels together with IBA remains (above) indicate that the collapsed pile has not been very active during the last few thousand years.

\section{CONDENSATION BY CONVECTIVE AIR CURRENTS}

Some collapse domes have ceased collapsing a long time ago, followed by thermal vapor convective remodeling. The top of such high domes is closer to the surface, thus exposing significantly cooler rock surfaces (compared with cave air), at least during the winter, allowing convection flow and condensation corrosion.

Indeed, high humidity and $\mathrm{CO}_{2}$ at the inner high points of the cave (Fig. 9) suggest that the warm air of the cave rises to the higher points where cool rock causes the vapor to condense, absorbing $\mathrm{CO}_{2}$ and giving rise to condensation corrosion while the air is cooling. Upon cooling, the air flows down, allowing additional rise of warm humid air. Eventually, the thermal-gradient produces condensation ceiling cupolas, which could lead to its misinterpretation as
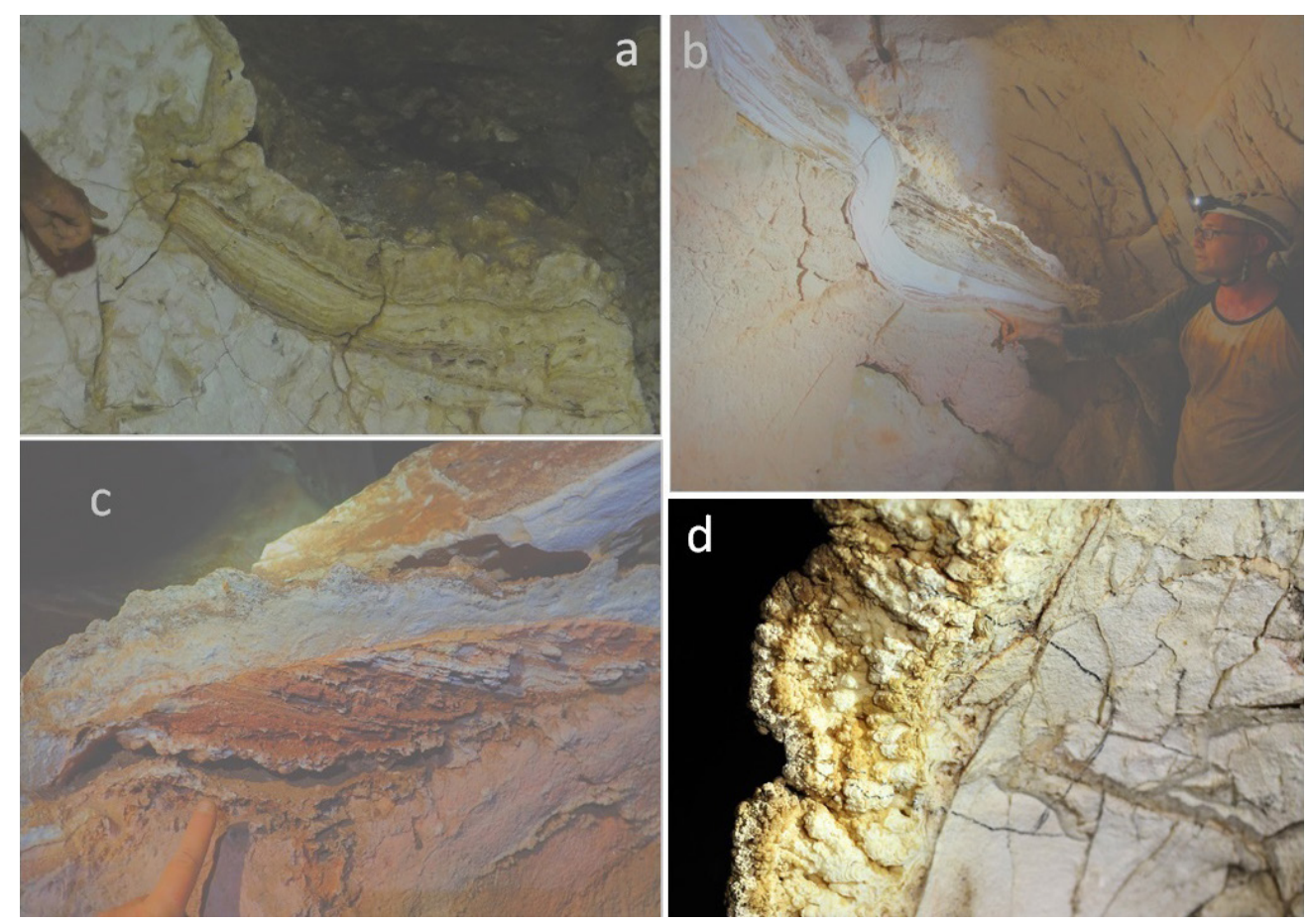

Fig. 14. a) Flowstone-like old deposit covered by popcorn-like deposit, both truncated by recent condensation corrosion at site S; b) Several generations of flowstone-like deposits divided by unconformities, both truncated by recent condensation corrosion, S; c) Laminar detritus (on bedrock), covered by popcorn-like deposit, upper part of passage zz'; d) Fractured-filling of calcite covered by popcorn, all truncated by recent condensation corrosion, T. Picture width $5 \mathrm{~cm}$; 

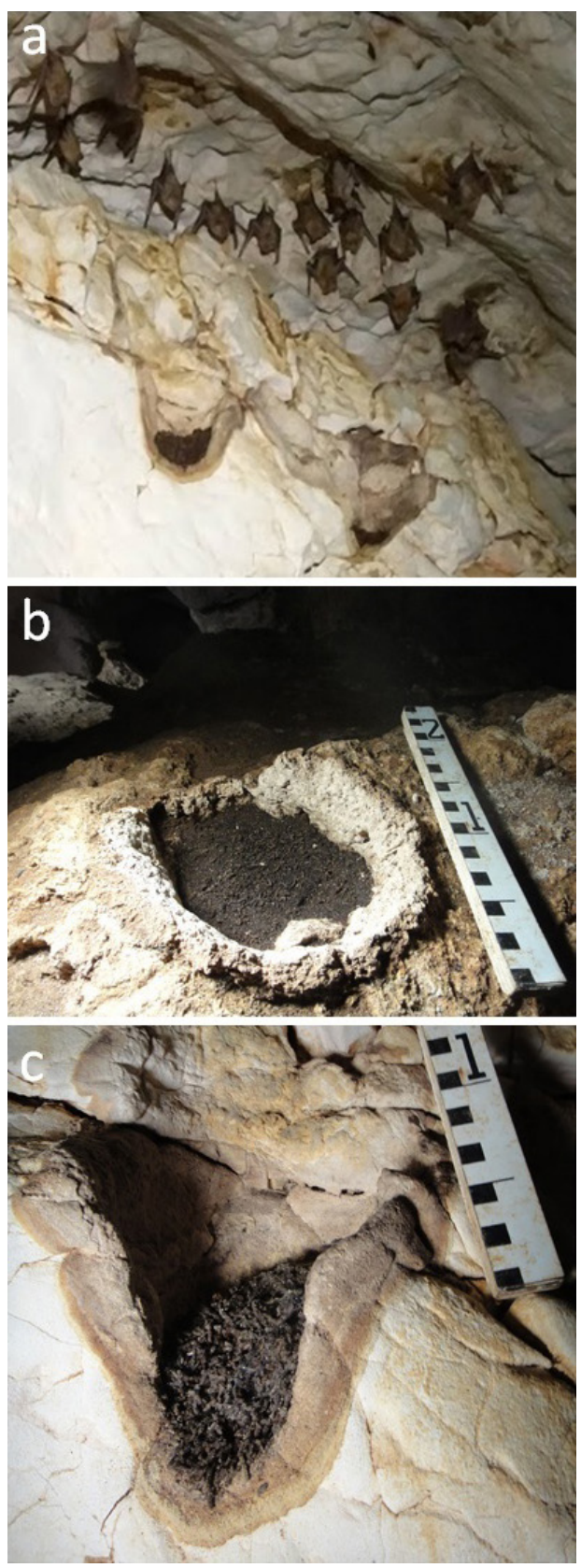

Fig. 15. Corrosion by bat guano with a reaction rims. a) Guano halfpocket on cave wall under Trident Leaf-nosed bats (Asellia tridens). Picture width $\sim 80 \mathrm{~cm}$; b) Guano pocket viewed from above; c) Guano half- pocket with reaction rim.

phreatic in origin (Audra, 2017). Such high dome-like cupolas appear at few places in the cave, such as the 'Cathedral' (g) and dome V.

More common are smaller, deeply incised corrosion pockets, up to few $\mathrm{m}$ in size, developed along ceilings, walls and in some high parts of the cave, even on the bottom of passages (Fig. 16a-c). The pockets and cupolas usually do not have a fissure control or indications of water input or output. The rocky wall of the pockets at the inner parts of the cave is commonly soft and powdery, extending into the wall up to a few $\mathrm{cm}$, occasionally $>10 \mathrm{~cm}$, eventually passing into hard, unaltered limestone.

The lower parts of the pockets are commonly covered by cave popcorn or coralloid deposits (Fig. 13b, 14d, and $16 \mathrm{~d})$. The lower popcorn and the upper corroded pockets are commonly divided by a sub-horizontal line (Fig. 17a). Some corroded pockets intersect other pockets including their associated popcorn, showing generations of pockets, and forming a clear cross section of the older pocket-popcorn systems (Fig. 17b-d).

The observed sections show that some popcorn was deposited over previous layered deposits, composed in some places of flowstone-like calcite (Fig. 14a,b), and in others of detrital silt and laminated sediment (Fig. 14c).

The outer parts of the cave (Fig. 7A,B,C,D) are presently well-aerated by the dry desert atmosphere. Dry air flowing into the cave mixes with internal warm and moist air, decreasing its temperature and relative humidity. The cave walls at this part have hard bedrock surfaces.

The passage into the inner parts of the cave has tight squeezes, restricting ventilation. Condensation is still active there and can be observed in some places, while near the entrance the low humidity probably eliminates the potential of condensation.

The coupled corrosion pockets and associated popcorn-coralloid deposits are attributed to local convection air currents. As in the high domes, the rising warm, humid and buoyant air appears to condense on high surfaces, absorbing $\mathrm{CO}_{2}$, subsequently corroding the surface. For condensation to proceed, this heat has been removed through solidstate thermal conduction and/or by downward flow of the condensate (Dreybrodt et al., 2005; Dublyansky et al., 2017).

The cooled air loaded with aerosols flows downwards and deposits popcorn.

Old flowstone-like deposits observed at the inner parts of the cave appear to be in close association with popcorn deposits and corrosion pockets (Fig. 14a,b). Both types of deposit may indicate a downward film of condensate, depositing flowstone and popcorn beneath condensation centers. The abundance of these deposits may indicate larger amounts of condensed water in the past, possibly associated with a nearby thermal water table. No flowstone is currently being deposited within the cave.

\section{FAUNA}

'A'rak Na'asane Cave includes several ecological niches, each niche inhabited by unique fauna and harbors an assemblage with different species composition. The ecological niches differ in their distance from the cave opening, relative humidity, temperature and in their floor cover structure. The cave is inhabited by two species of insectivorous bats (present in different areas in the cave), few species of detritivores: two species of woodlice, one troglobitic silverfish, one psocopteran species, collembolas and about four species of blind troglobitic arachnids of different taxa, now under investigation, most probably undescribed species.

The main energy source in the inner parts of the cave is bat guano. Bat urea on the ceiling supports some urea stalactites (Fig. 13a; Audra et al., 2017). Trident Leaf-nosed bats (Asellia tridens Geoffroy, 1813) inhabit these parts, particularly during the winter, when their number amounts to thousands. They provide 

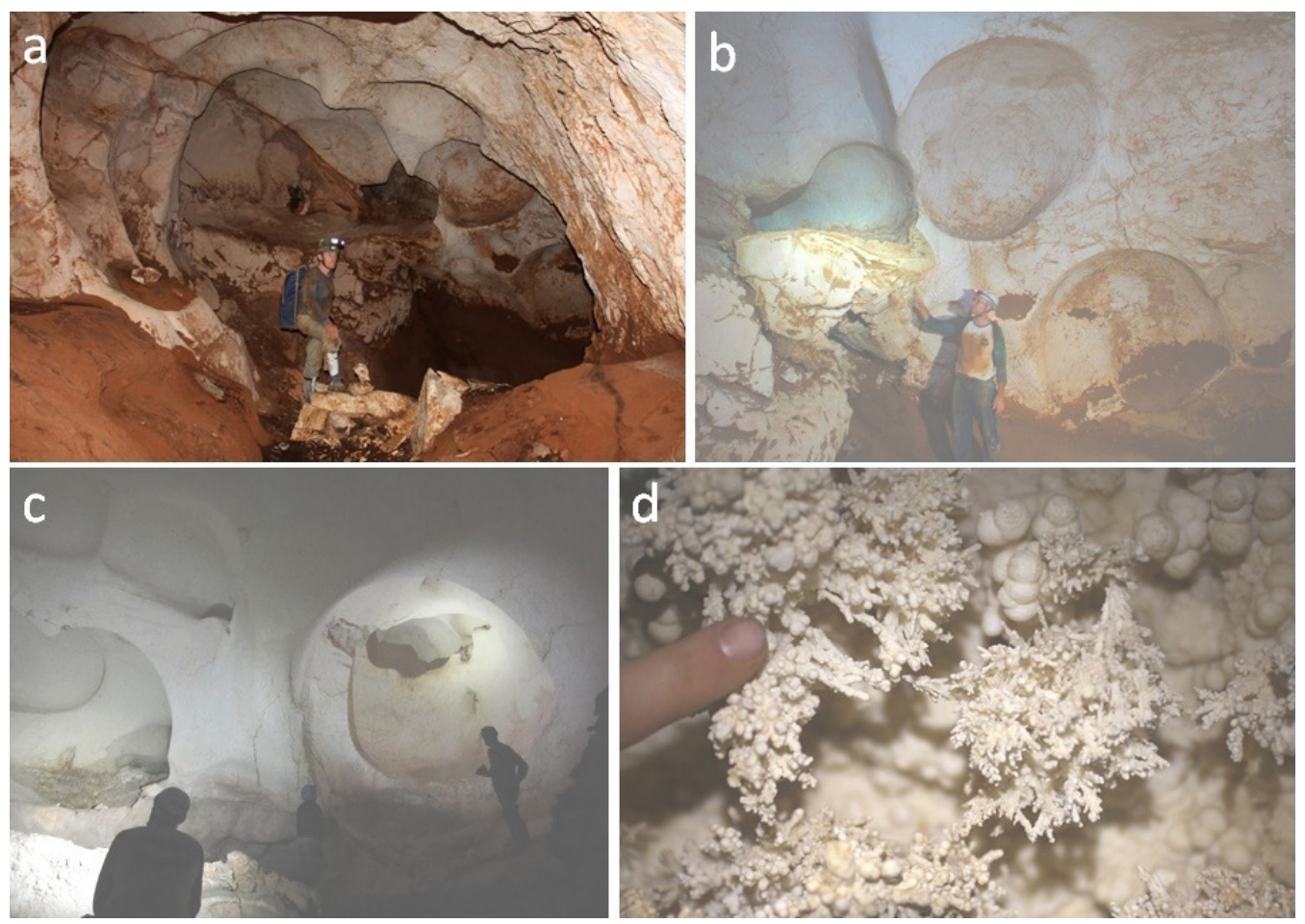

Fig. 16. Effects of convectional condensation corrosion and deposition. a) Cupolas and mudbank covering the lower passage, including dissolution pockets, site S; b) Solutional pockets cutting fractured limestone. Note calcite deposits (left) and mudbank fill (lower right); c) Pocket cutting a passage; d) Coralloid deposit on popcorn.

guano which is consumed by a rich invertebrate fauna flourishing on this organic resource. Most of the cave-rich fauna, as expected, is correlated with the fresh and moist bat guano. Pellegrini \& Ferreira (2013) showed that species richness and diversity are positively correlated with moisture, while considering the cave community associated with bat guano and the adjacent soil.
Sections A, B, D - these outer sections are characterized by low (compared with inner sections) winter temperature and low relative humidity (24.2$25.4^{\circ} \mathrm{C}$ and $71.5-87.3 \%$, respectively). The fauna found in these sections is connected to the fauna found outside of the cave. These sections are actively inhabited by Lesser rat-tailed bats (Rhinopoma hardwickei Gray, 1831), producing a strong odor due
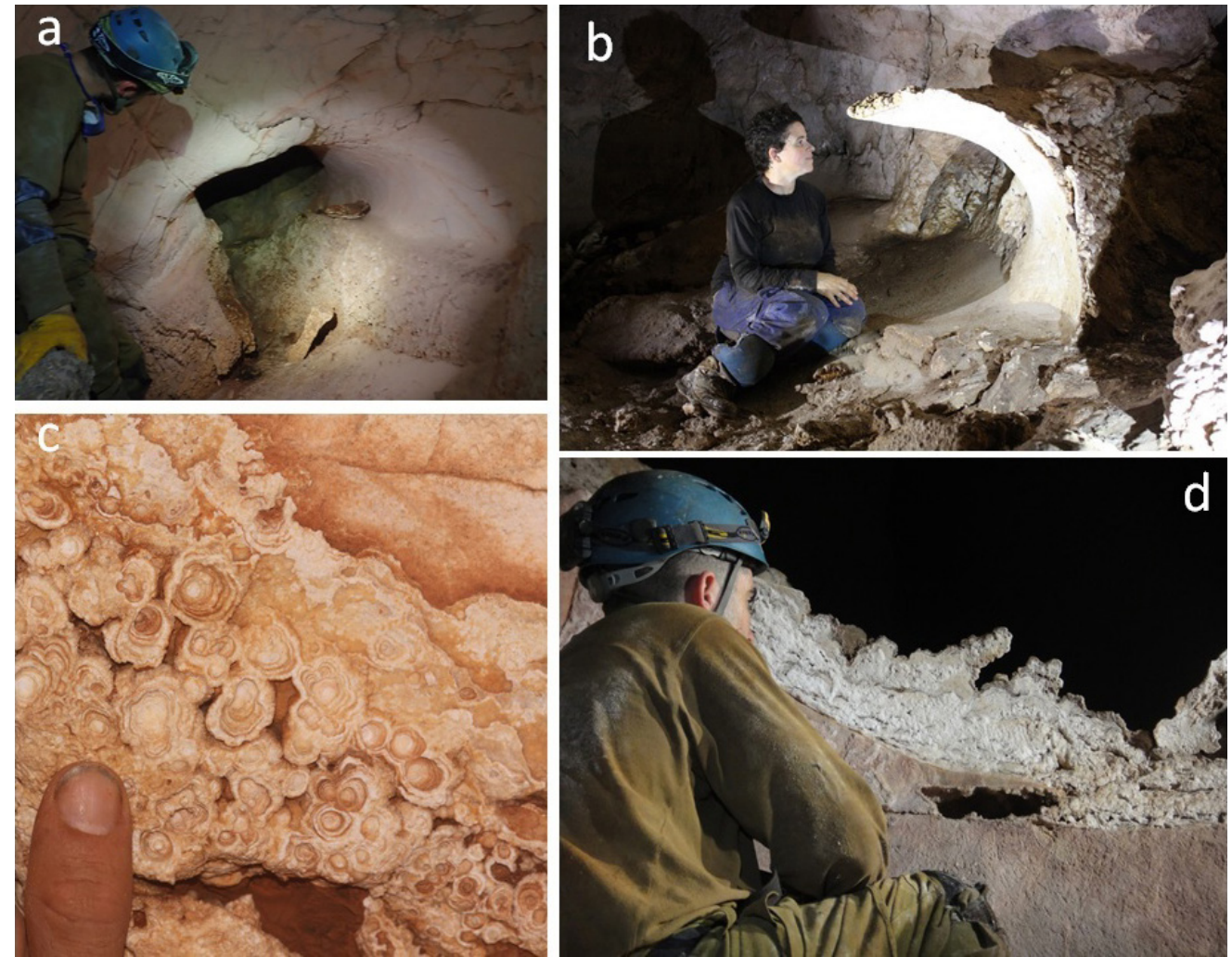

Fig. 17. Effects of condensation corrosion. a) Condensation corrosion in upper wall of passage underlain by popcorn deposit; b) Dissolution notch with overgrowth of popcorn, undercut by condensation corrosion; c) Close view of popcorn deposit and bedrock, both truncated by condensation corrosion; d) Truncated coralloids on corroded limestone. 
to their feces and urine. On 31 ${ }^{\text {st }}$ December 2017 we observed an Egyptian fruit-bat (Rousettus aegyptiacus Geoffroy, 1810) corpse that had been decomposing for a few weeks at section A (Fig. 18a). This is the first observation of this species in the cave, out of more than a dozen visits during the past years. The presence of this fruit-eating species may explain the appearance of a small seedling of a non-indigenous Ficus tree species growing on the wall at the entrance section.

The dry loose dusty deposit at the bottom of the outer sections is inhabited by the Egyptian desert cockroach (Polyphaga aegyptiaca Linnaeus, 1758) in high abundance (especially in section A). Unidentified small spiders were active on the bat guano which was deposited on top of a layer of goat feces. Remnants of Hymenopterans (ant wings, bee's body parts), antlions (Palpares sp. wings) and moths (wings and heads) were deposited on the floor, most probably uneaten parts of bat's prey. Feces of Indian crested porcupine (Hystrix indica Kerr, 1792) were also present in these sections. We encountered only small numbers of the soft tick Ornithodoros tholozani (Laboulbène \& Mégnin, 1882) which is known to be abundant in Israeli caves inhabited by large mammals.

One of the local cave predators found in these sections is the recently described troglophile pholcid spider, Artema nephilit (Aharon et al., 2017). Artema nephilit is distributed in caves along the Jordan Rift Valley and is one of the largest pholcid spiders in the world. This spider builds a large, non-sticky silk web on the ceiling and walls of caves, and has preference for the entrance and middle parts of caves rather than the deeper darker section.

The south-western part of the cave, section d-d", is composed of narrow net-like passages with dark, damp and compact floor cover. Bat guano, porcupine feces and spines are present on the floor. This section is different from section D by its higher humidity level (relative humidity 93.4-97\%). This may be associated with a large wall, situated in the middle of a medium hall, just before the entrance to the narrow cavities, which decreases ventilation. Large numbers of troglobite psocopterans were observed foraging on the guano, mainly in this section (Fig. 18b); interestingly, they were absent in the inner parts of the cave (from section G onwards). A unique brown-reddish layer, found only in this section, appears to be an unidentified Cyanobacteria, growing and covering parts of the walls in a thick layer and in the surface of cracks as it forms a fine delicate lamella (Fig. 18c).

Section E-F - in these sections we encountered different conditions of humidity and soil characteristics. Both temperature and relative humidity are higher (25.3-25. $7^{\circ} \mathrm{C}$ and $96.4 \%$, respectively) than in sections A, B, D. Hence, the floor unconsolidated cover is characterized by less dry powder-like particles than in sections A, B, and D, however it is not wet or damp. Few but unique organisms were found in these sections: an undescribed mite was found dwelling on the floor cover and underneath small stones, and in proximity to few specimens of a depigmented troglobite psocopteran as observed in large numbers at the humid south-western section dd". In those sections there was no deposition of bat guano.

Sections G-M-N - from section G and deeper, the humidity is higher (temperature $25.7-26.1^{\circ} \mathrm{C}$, relative humidity $95.8-96.6 \%$ ) and the floor cover is damp. Along the relatively narrow long section $G$ there is hardly any bat guano. Few specimens of woodlice and theraphosid spider were observed in the large hall, opened widely at $t$. In the eastern part of this hall, the high "Cathedral" hall g slopes upwards, having very humid and wet conditions (temperature $26^{\circ} \mathrm{C}$, relative humidity $98.9 \%$ ). Here is the first appearance of the unique faunal assemblage inhabiting the inner wet parts of the cave. This assemblage appears also deeper in section $\mathrm{R}$ and in the humid large hall $z-z^{\prime}$ (especially on rich accumulations of bat guano). Few hundreds of Trident Leaf-nosed bats appear at the high chimney-like ceiling of $\mathrm{g}$. These bats have been estimated to number tens of thousands on our visits to chamber g-M-N during the winters of 19791980 , so their numbers have drastically decreased at this part of the cave. The guano and associated Arthropoda assemblage at this part of the cave have also decreased dramatically from 1980 to 2017 .

On the floor of g, large theraphosid spiders and woodlice are present on the bat-guano pile, together with Loxosceles spiders, unidentified large troglobite silverfish of the Nicoletiidae family (Escherich, 1905), and an undescribed arachnid. This assemblage is present at the following sections and is absent at the previous sections and sections M-N. A few small pits in the entrance of the "Cathedral" hall accumulate (condensation?) water, where we found few collembolas on the water surface. It appears to be the single locality of this taxon at the whole cave.

Sections R, S, T, U, and V - these sections are characterized by higher humidity (temperature $25.5-25.8^{\circ} \mathrm{C}$, relative humidity $\left.98.1-99.5 \%\right)$ and the floor cover is wet and muddy. Sections R, S are relatively narrow passages while sections $T, U, V$ are an elongated large hall inhabited by 500-1000 specimens of Trident Leaf-nosed bats (Fig. 18d). This large passage is the main gathering place, where the bats presently congregate during the winter. However, it is not clear whether the bats fly all the way from the main cave opening, through long and narrow cavities or otherwise through unknown hidden openings at the cave ceiling. The floor of the hall is covered by massive collapsed rocks; between them a thick layer of guano is deposited, which together with corpses of bats is enriching the cave with organic resources. Two species of unidentified woodlice (Isopoda: Oniscidea) were observed in these sections: one was feeding on guano (Fig. 18e) while the other was observed on a bat corpse covered with brown fungi (Fig. 18f). Theraphosid spiders are abundant in large numbers in these sections, as well as in other parts of the cave, one specimen was observed consuming a woodlouse (Fig. 18g). Large troglobite silverfish (Insecta: Zygentoma) with long appendages were observed mainly in these sections as well as in other humid and wet parts of the cave, foraging near guano, on rocks and on wet muddy soil (Fig. 18h). Four additional arachnid species were 

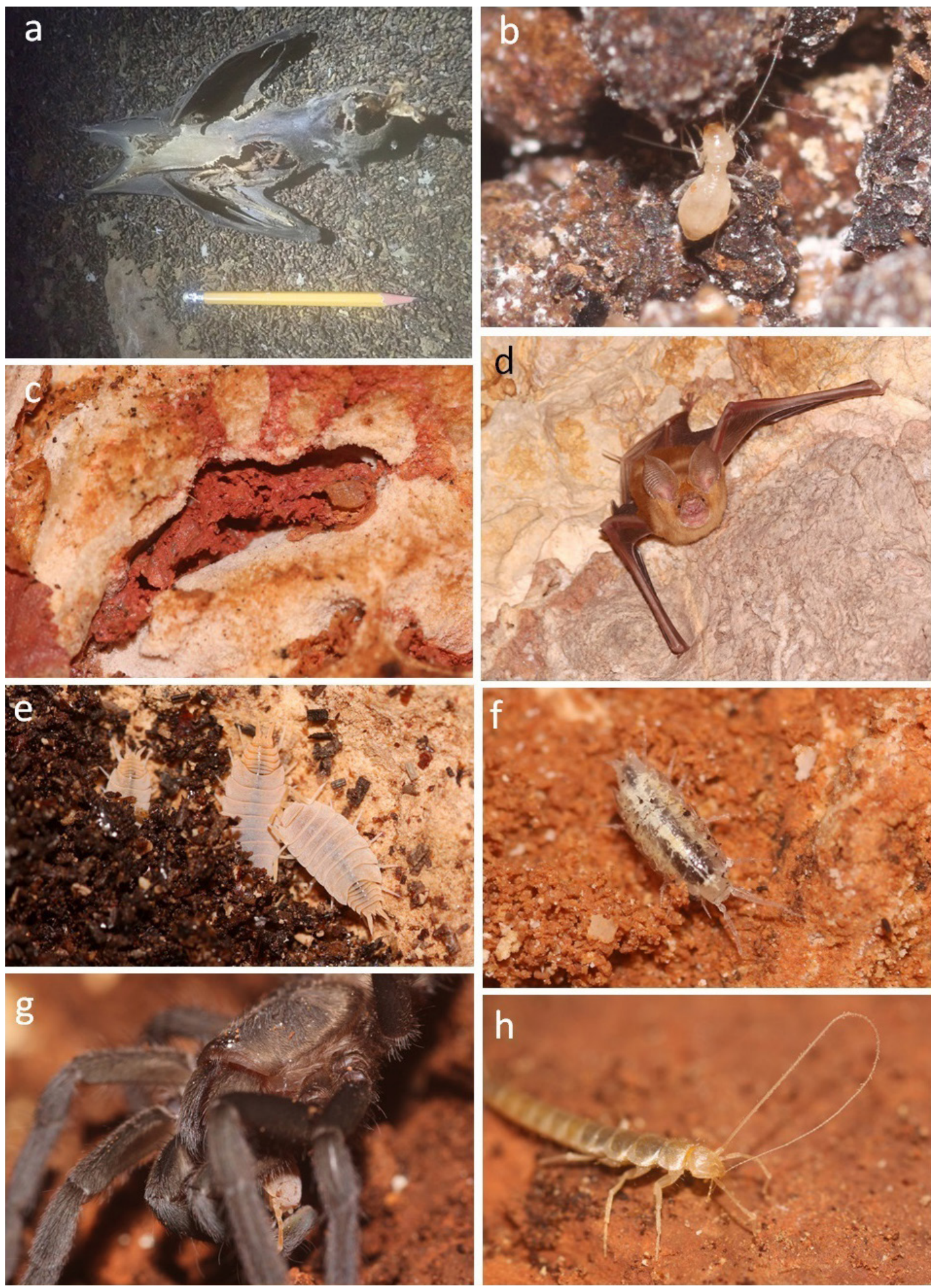

Fig. 18. a) Egyptian fruit-bat (Rousettus aegyptiacus) found dead at section A; b) A depigmented psocopteran foraging on bat guano. Picture width $\sim 0.7 \mathrm{~cm} ; \mathrm{c}$ ) A brown-reddish layer, growing on the walls of section DA, appears to be an unidentified Cyanobacteria. Picture width $\sim 15 \mathrm{~cm}$; d) A Trident Leaf-nosed bat (Asellia tridens) clinging on a wall at section W. Picture width $\sim 24 \mathrm{~cm} ; \mathrm{e}$ ) Three specimens of the abundant isopod species foraging on fresh guano. Isopodes are among the most important detritivore species in the cave, especially abundant at the deeper sections. Picture width $\sim 2.5 \mathrm{~cm}$; f) A less common isopod species, observed at the "Cathedral" hall and at section T. Picture width $\sim 1 \mathrm{~cm} ; \mathrm{g}$ ) A large theraphosid spider consuming a woodlouse. Picture width $\sim 2.5 \mathrm{~cm} ; \mathrm{h}$ ) An eyeless, troglobite silverfish found on the humid and deep section, cleaning its extremely long antennae. Picture width $\sim 3 \mathrm{~cm}$.

collected and are being investigated, most of them, if not all, are undescribed species.

\section{SOURCE OF HEAT}

In spite of the tectonic uplift and erosional breaching modifications (above), the inner cave still supports humid and warm conditions today (Fig. 9). The inner cave temperature, $\sim 26^{\circ} \mathrm{C}$, is $\sim 5^{\circ} \mathrm{C}$ warmer than the subaerial mean annual temperature $\sim 21^{\circ} \mathrm{C}$. This elevated temperature needs to be explained.

The oldest rock outcrop along the Ramallah anticline is Jurassic, appearing where the anticline is deeply breached by tectonics and erosion, $35 \mathrm{~km}$ NNE of 'A'rak Na'asane. At this point, Hamam el Malih springs allows access to the deep thermal water of the Jurassic aquifer. At $34-35^{\circ} \mathrm{C}$, Hamam el Malih water is $\sim 10^{\circ}$ warmer than nearby fresh epigene groundwater, 
and is considerably richer in solutes (TDS $~ 3500 \mathrm{mgl}^{-1}$ ). In particular, a large solute enrichment relative to nearby epigene water is observed in the following ions: $\mathrm{Na}, \mathrm{Cl}, \mathrm{SO}_{4}, \mathrm{~K}, \mathrm{Br}, \mathrm{Sr}, \mathrm{Ba}$, and Li (Siebert et al., 2012). Although closer to 'A'rak Na'asane the deep aquifer has not been penetrated to our knowledge, there are many indications that it does occur under the Syrian Arc structures and its water still rises along the faults which underlie the monoclines of these structures. For example, rising of deep, old water along the Auja Monocline, $22 \mathrm{~km}$ SSW of the cave (Fig. 4), is indicated by low radiocarbon content of 'Ein Fara water, which contains 60-70\% old flow (Kroitoru, 1987; Frumkin et al., 2017a), contrasting with younger groundwater further downstream.

The source of the high temperatures and humidity in 'A'rak Na'asane can hardly be attributed only to physical, chemical or biological processes within the cave, as these conditions occur in large volumes of cave voids, and seem not to vary considerably within the inner cave, across areas with different physical, chemical or biological processes. In addition, vadose drip water has not been observed in the cave, and dripstones are generally absent.

While the cave is positioned today above the water table, the most likely source of its humidity and heat may be rising vapor or solid-state thermal conduction from the underlying thermal water. Similar flow of humid, warm air occurs also in many blowholes along the western shoulders of the Dead Sea transform (e.g., cave A16, Schwager \& Miron, 1990).

The modern decreasing activity of condensation corrosion may indicate that intensive condensation corrosion had been more active during the latest stages of hypogene karstification when the thermal water was still closer to the cave.

\section{CONCLUSIONS}

A desert hypogene cave can develop unique microenvironments following its speleogenesis. 'A'rak Na'asane Cave developed two main cave environments. The outer zone of the cave is associated with the outside environment because of the large entrance enhancing ventilation, as reflected by several features: temperature, humidity, gases, archaeology and faunal assemblage. This environment has been hospitable for entry of fauna, as well as refuge of humans, but has not been morphologically dynamic since the formation of the cave entrance.

Conversely, the inner cave is very humid and warm. The high temperature and humidity favor dynamic modification of the cave and unique faunal assemblage, but unfavor human use.

The most significant post-speleogenetic development is condensation corrosion and associated popcorn deposition. Another process is bedrock alteration and dissolution under deposits of bat guano, as indicated by solution pockets and alteration rims (Fig. 15).

The high humid and warm air of the inner cave may be associated with rising thermal water underlying the cave. Condensation corrosion at the inner parts of the cave seems to become progressively inactive today, possibly indicating a gradual change in the microclimate inside the cave. The most likely reasons are falling of the thermal water table and/or increased ventilation caused by the intersection of the cave with the subaerial surface and formation of the entrance. In addition to the present entrance, increasing caveto-surface connection is indicated by collapse piles, flood water invasion, and possibly by the large bat community at the innermost parts of the cave, which may enter the cave by a yet-unknown additional opening(s).

The warm and humid air inside 'A'rak Na'asane appeals to thousands of Trident Leaf-nosed bats which spend the winter inside the cave. Their guano supports a rich invertebrate fauna. On the other hand, humans found this environment too harsh, and preferred the outer parts of the cave even under enemy threat. Rare occasions of human entry into the inner cave support this scenario by the small number of artifacts compared with the outer parts of the cave. The small cairns in the largest hall, possibly erected during the Intermediate Bronze Age, constitute one of the more enigmatic phenomena related to past cave occupations in the southern Levant, and may relate to symbolically-loaded activities associated with IBA penetrations deep into maze caves of this region.

\section{REFERENCES}

Aharon S., Huber B.A. \& Gavish-Regev E., 2017 - Daddylong-leg giants: revision of the spider genus Artema Walckenaer, 1837 (Araneae, Pholcidae). European Journal of Taxonomy, 376: 1-57. https://doi.org/10.5852/ejt.2017.376

Audra P., 2017 - Hypogene caves in France. In: Klimchouk A., Palmer A.N., De Waele J., Auler A.S. \& Audra P. (Eds.), Hypogene karst regions and caves of the world. Springer, Cham, p. 61-83. https://doi.org/10.1007/978-3-319-53348-3 3

Audra P., Bosák P., Gázquez F., Cailhol D., Skála R., Lisá L., Jonásová S., Frumkin A., Knez M., Slabe T. \& Hajna N.Z., 2017 - Bat urea-derived minerals in arid environment. First identification of allantoin, $\mathrm{C}_{4} \mathrm{H}_{6} \mathrm{~N}_{4} \mathrm{O}_{3}$ in Kahf Kharrat Najem Cave, United Arab Emirates. International Journal of Speleology, 46 (1): 81-92. https://doi.org/10.5038/1827-806X.46.1.2001

Bar O., Zilberman E., Feinstein S., Calvo R. \& Gvirtzman Z., 2016 - The uplift history of the Arabian Plateau as inferred from geomorphologic analysis of its northwestern edge. Tectonophysics, 671: 9-23. https://doi.org/10.1016/j.tecto.2016.01.004

Begin Z.B., 1974 - The geological map of Israel, sheet 9-III, Jericho, with explanatory notes. Scale 1:50,000, Geological Survey of Israel, Jerusalem.

Chavez T. \& Reehling P., 2016 - Proceedings of deepkarst 2016: origins, resources, and management of hypogene karst. National Cave and Karst Research Institute, Carlsbad, New Mexico, 203 p.

Damati E. \& Erlich Z., 1981 - A hoard of denarii and a Tridrachm from Wadi ed-Daliyeh. Israel Numismatic Journal, 5: 33-37.

Dublyansky Y., Klenke J. \& Spötl C., 2017 - Condensation corrosion speleogenesis in the Amargosa Desert and the Tecopa Basin. In: Klimchouk A., Palmer A.N., De Waele J., Auler A.S. \& Audra P. (Eds.), Hypogene karst regions and caves of the world. Springer, Cham, p. 565-573. https://doi.org/10.1007/978-3-319-53348-3 35 
Dreybrodt W., Gabrovšek F. \& Perne M., 2005 Condensation corrosion: a theoretical approach. Acta Carsologica, 34 (2): 317-348. https://doi.org/10.3986/ac.v34i2.262

Dušek J., 2007 - Les manuscrits araméens du Wadi Daliyeh et la Samarie vers. Culture and history of the ancient Near East, 30, Brill, Leiden, 700 p.

Eshel H., 1998 - The finds from the Cave of 'Araq enNa'asaneh in Wadi ed-Daliyeh. In: Eshel H. \& Amit D. (Eds.) Refuge caves of the Bar-Kokhba Revolt. Eretz, Tel-Aviv, p. 71-76 (In Hebrew).

Eshel H., 1999 - A note on the nature of caves used for habitation in the Intermediate Bronze period. Niqrot Zurim, 20: 19-22 (In Hebrew).

Fleischer L. \& Gafsou R., 2000 - Top Judea Group - digital structural map of Israel. Scale 1:200,000, Geophysical Institute of Israel, Lod.

Frumkin A. (Ed.), 2015 - Atlas of the Holey Land - Judean Desert Caves. Magnes, Jerusalem, 458 p (Hebrew).

Frumkin A. \& Langford B., 2015 - Nahal Dlayah, Samaria, Israel - A unique concentration of karstic caves and hundreds years of refuge. In: Tavger A., Amar Z. $\&$ Billig M. (Eds.), In the Highland's Depth, Ephraim Range and Binyamin Research Studies 5. Ariel-Neve Tzuf, p. 95-110 (In Hebrew).

Frumkin A., Langford B., Lisker S. \& Amrani A., 2017 - Hypogenic karst at the Arabian platform margins: implications for far-field groundwater systems. Bulletin of the Geological Society of America, 129 (11-12): 1636-1659. https://doi.org/10.1130/B31694.1

Frumkin A., Langford B. \& Porat R., 2017 - The Judean Desert - the major hypogene cave region of the southern Levant. In: Klimchouk A., Palmer A.N., De Waele J., Auler A.S. \& Audra P. (Eds.), Hypogene karst regions and caves of the world. Springer, Cham, p. 463-477. https://doi.org/10.1007/978-3-319-53348-3_28

Gropp D.M., 2001 - Wadi Daliyeh II: the Samaria Papyri from Wadi Daliyeh. [DJD XXVIII], Clarendon Press, Oxford, $116 \mathrm{p}$.

Hilman B. \& Angert A., 2016 - Measuring the ratio of $\mathrm{CO}_{2}$ efflux to $\mathrm{O}_{2}$ influx in tree stem respiration. Tree Physiology 36 (11): 1422-1431. https://doi.org/10.1093/treephys/tpw057

Joffe S. \& Garfunkel Z., 1987 - Plate kinematics of the circum Red Sea - a re-evaluation. Tectonophysics, 141 (1-3): 5-22.

https://doi.org/10.1016/0040-1951(87)90171-5

Klimchouk A., 2017 - Types and settings of hypogene karst. In: Klimchouk A., Palmer A.N., De Waele J.,
Auler A.S. \& Audra P. (Eds.), Hypogene karst regions and caves of the world. Springer, Cham, p. 1-39. https://doi.org/10.1007/978-3-319-53348-3 1

Klimchouk A., Palmer A.N., De Waele J., Auler A.S. \& Audra P. (Eds.), 2017 - Hypogene karst regions and caves of the world. Springer, Cham, $911 \mathrm{p}$. https://doi.org/10.1007/978-3-319-53348-3

Kroitoru L., 1987 - The characterization of flow system in carbonate rock by means of groundwater parameters: Central Israel. Unpublished Ph.D. thesis: Rehovot, Israel, Weizmann Institute of Science, $124 \mathrm{p}$.

Lapp P.W. \& Lapp N.L., 1974 - Discoveries in the Wadi ed-Daliyeh. The Annual of the American Schools of Oriental Research, 41: 1-106. https://doi.org/10.2307/3768541

Lisker S., Vaks A., Bar-Matthews M., Porat R. \& Frumkin A., 2010 - Late Pleistocene palaeoclimatic and palaeoenvironmental reconstruction of the Dead Sea area (Israel) based on speleothems and cave stromatolites. Quaternary Science Reviews, 29: 1201-1211. https://doi.org/10.1016/j.quascirev.2010.01.018

Pellegrini T.G. \& Ferreira R.L., 2013 - Structure and interactions in a cave guano-soil continuum community. European Journal of Soil Biology, 57: 19-26. https://doi.org/10.1016/j.ejsobi.2013.03.003

Schwager G. \& Miron Y., 1990 - Caves survey in Mount Berenike. Niqrot Zurim, 17: 61-76 (In Hebrew).

Shahar J., 1994 - The Syrian arc system: an overview. Palaeogeography, Palaeoclimatology, Palaeoecology, 112 (1): 125-142.

https://doi.org/10.1016/0031-0182(94)90137-6

Siebert C., Rosenthal E., Möller P., Rödiger T. \& Meiler M., 2012 - The hydrochemical identification of groundwater flowing to the Bet She'an-Harod multiaquifer system (Lower Jordan Valley) by rare earth elements, yttrium, stable isotopes $(H, O)$ and Tritium. Applied Geochemistry, 27 (3): 703-714.

https://doi.org/10.1016/j.apgeochem.2011.11.011

Vaks A., Bar-Matthews M., Ayalon A., Schilman B., Gilmour M., Hawkesworth C.J., Frumkin A., Kaufman A. \& Matthews A., 2003 - Paleoclimate reconstruction based on the timing of speleothem growth, oxygen and carbon isotope composition from a cave located in the rain shadow in Israel. Quaternary Research, 59: 182-193. https://doi.org/10.1016/S0033-5894(03)00013-9

Winn Leith M.J., 1997 - The Wadi Daliyeh Seal Impressions, Wadi ed-Daliyeh (Vol. 1), Discoveries in the Judean Desert XXIV. Clarendon Press, Oxford. 